\title{
A Review on Biological Processes for Pharmaceuticals Wastes Abatement-A Growing Threat to Modern Society
}

\author{
Filomena Costa,*ㄹ Ana Lago, Verónica Rocha, Óscar Barros, Lara Costa, Ziva Vipotnik, Bruna Silva, ${ }^{\circledR}$ \\ and Teresa Tavares
}

Centre of Biological Engineering, University of Minho, Campus de Gualtar, 4710-057 Braga, Portugal

Supporting Information

ABSTRACT: Over the last decades, the production and consumption of pharmaceuticals and health care products grew manifold, allowing an increase in life expectancy and a better life quality for humans and animals, in general. However, the growth in pharmaceuticals production and consumption comes with an increase in waste production, which creates a number of challenges as well as opportunities for the waste management industries. The conventional current technologies used to treat effluents have shown to be inefficient to remove or just to reduce the concentrations of

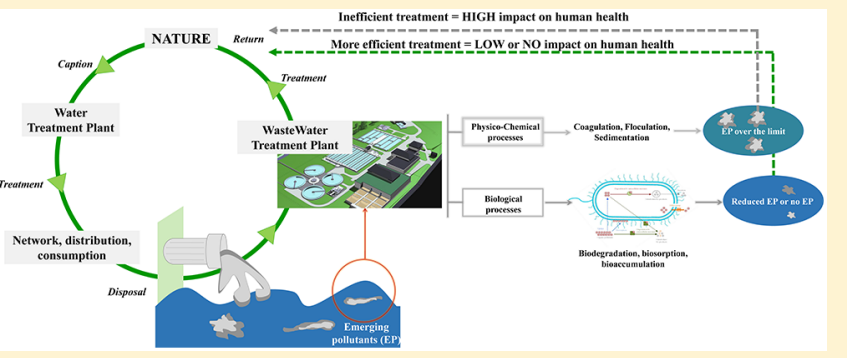
these types of pollutants to the legal limits. The present review provides a thorough state-of-the-art overview on the use of biological processes in the rehabilitation of ecosystems contaminated with the pharmaceutical compounds most commonly detected in the environment and eventually more studied by the scientific community. Among the different biological processes, special attention is given to biosorption and biodegradation.

\section{INTRODUCTION}

The burst of anthropogenic activity and industrialization has led to the production of enormous amounts of toxic residues and aqueous effluents containing a diversity of hazardous substances such as organic contaminants (volatile organic compounds, pharmaceutical and personal care products, and dyes, among others) or metals and metallic/metalloid compounds. $^{1-4}$ Among these pollutants, pharmaceutical compounds stand out as they are able to remain biologically active for long periods of time, and the vast majority of their metabolites and respective ecotoxicity are either unknown or poorly understood. The main source of pharmaceuticals entrance into the environment includes human and animal ingestion, followed by excretion and disposal in wastewater that will end at the wastewater treatment plants (WWTP). ${ }^{5}$ Moreover, hospitals, veterinary clinics, industrial wastewater, and illegal and uncontrolled drugs discharge, ${ }^{6}$ as well as the runoff associated with cattle breeding and releases from medicated feeds in aquaculture, can also represent a significant source of aquatic contamination. The pharmaceuticals most often detected in aquatic systems comprise acetaminophen, caffeine, carbamazepine, cotinine, ibuprofen, and sulfamethoxazole. Among these, acetaminophen and caffeine are the least recalcitrant, whereas carbamazepine, cotinine, and sulfamethoxazole are more recalcitrant. Once these compounds enter the aquatic matrices, they may be transformed via sediment sorption, photolysis, micro- and macroorganisms assimilation, or microbial activity. ${ }^{7}$ The continuous development and investment on new and improved formulas (Supporting
Information (SI), Figure S1) increase and exacerbate the problems previously mentioned.

The entrance of these contaminants into the environment makes them accountable for the instability and fragility of the ecosystems ${ }^{8}$ and for their detrimental impact on public health. ${ }^{3,9}$ The growing awareness and concern of the overall population regarding the impact of these pollutants has stimulated and even demanded the development and application of stricter legislation and more efficient detection and treatment measures, ${ }^{3}$ particularly ecofriendly measures that may use innocuous microorganisms or their aggregates. ${ }^{2,10}$

Although stricter legislation has been implemented in most developed and developing countries, this does not necessarily imply more on-site or in-plant systems able to efficiently treat contaminated water. Before the implementation of such measures, a substantial amount of research and engineering work must be conducted prior to systems design. ${ }^{10}$

To date, several techniques have been employed for the treatment of wastewater and industrial effluents. These techniques can be divided into two major groups: abiotic and biotic techniques. The abiotic ones cover physicalchemical processes like ion exchange, adsorption, precipitation, electrochemical and membrane technologies, ${ }^{10}$ oxidation with or without flame, air-striping, thermal degradation, condensation, and incineration. ${ }^{11,12}$ These are usually very expensive,

Received: December 11, 2018

Revised: May 20, 2019

Accepted: June 5, 2019

Published: June 19, 2019 


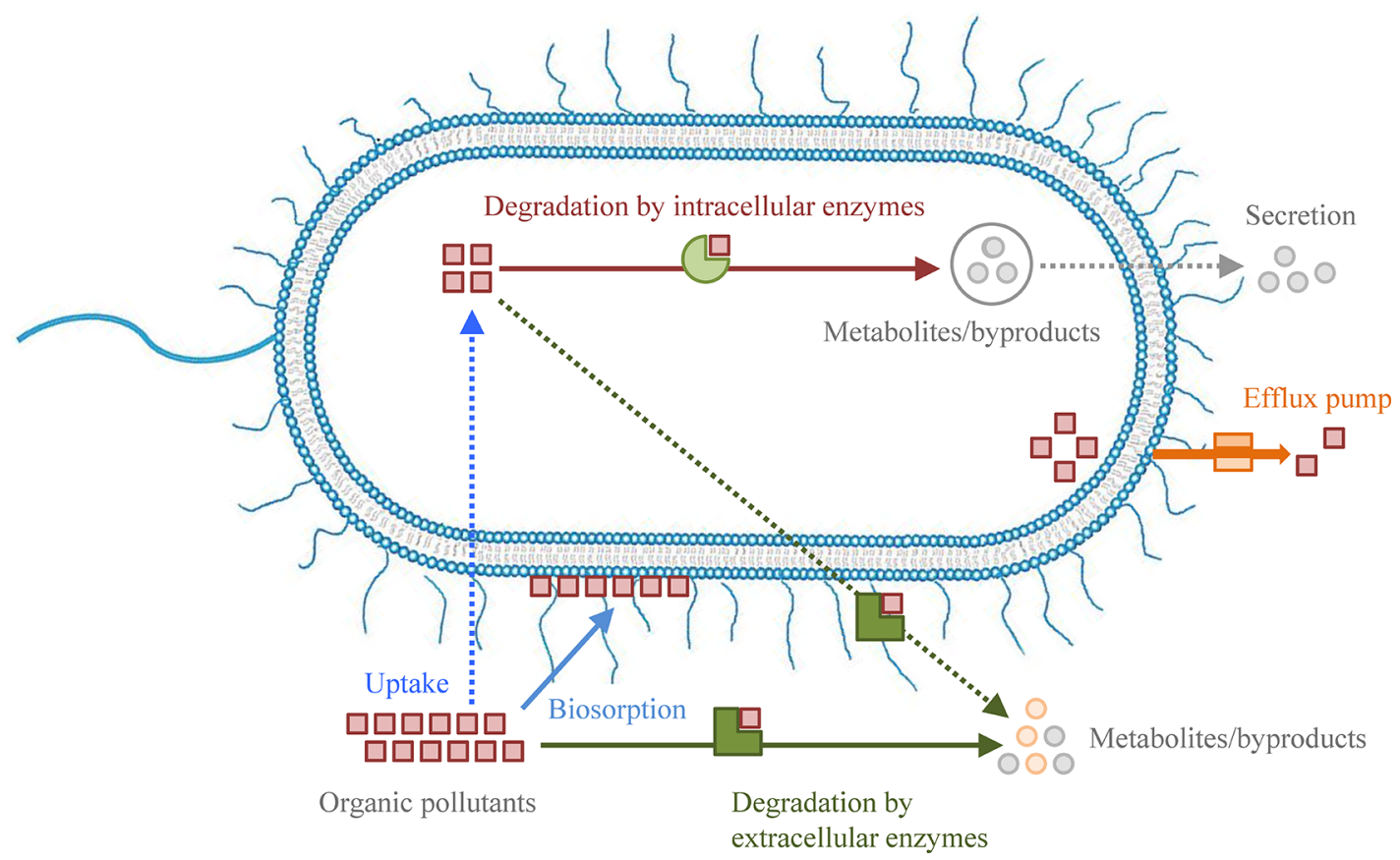

Figure 1. Possible biological interactions between cells and organic pollutants.

from operational, maintenance, and equipment perspectives, not ecofriendly, with efficiency dependent on pollutants concentrations, and they usually require a secondary treatment due to the production of toxic sludge and toxic gases such as $\mathrm{NO}_{x}{ }^{1,13}$ Some of them do not alter the chemical structure of the organic pollutants but simply transfer them to a different phase $^{14}$ not solving the actual problem. The biotic techniques cover processes like biodegradation, biosorption, bioremediation, ${ }^{15}$ and bioaccumulation. ${ }^{10}$ These biotic processes have been used for several decades in standard sewage and water treatments, as well as in auxiliary reed bed and wetlands approaches $^{3,9}$ and present several important advantages over the abiotic techniques; namely, they can be carried out in situ, usually present an eco-friendly character, and are cost effective. $^{11,15}$

A thorough review is now presented on the state-of-the-art usage of biological processes in the rehabilitation of ecosystems contaminated with the pharmaceuticals compounds most commonly detected in the environment and the main factors and limitations affecting the biological processes used and the strategies to overcome them. Among the different biological processes, special attention is given to biosorption and biodegradation processes.

\section{OVERVIEW OF BIOSORPTION AND BIODEGRADATION PROCESSES}

Biological processes include bioremediation, phytoremediation, biosorption, and biodegradation and can occur separately or simultaneously during the removal of pollutants, being influenced by numerous parameters ${ }^{2}$ (SI, Figure S2).

Microorganisms can participate in the treatment of contaminated effluents without undergoing any kind of human intervention (natural attenuation), and this can be enhanced by engineered techniques, either by the addition nutrients (biostimulation) or by the addition of supplemental microorganisms (bioaugmentation). In recent years, genetic recombination has been used to upgrade the biological capabilities of microorganisms leading to genetic-engineered microorganisms (GEM). The use of GEM in the field presents, however, several risks of ecological and environmental concern.

Biological processes are usually classified according to a set of parameters such as the involvement of metabolic or nonmetabolic pathways of entrapment or degradation of contaminants (Figure 1), the primary metabolic pathway used by the dominant group of active microorganisms, and the growth conditions.

According to the availability and use of oxygen, biological processes can be classified as aerobic, anaerobic, and anoxic, ${ }^{16}$ whereas according to the growth conditions, they can be classified as in suspended growth or as in attached growth in biofilm structures. ${ }^{17}$

2.1. Biosorption. The term biosorption has a multidimensional character, with a quite embracing definition that has evolved over the past years. The various aspects are related to the type of sorbate and the type of biosorbents employed, to the environmental conditions, to the diversity of the underlying mechanisms, and to the metabolic processes in the case of living organisms. ${ }^{18}$ The term was used for the first time by Ruchhoft in 1949 according to Volesky, ${ }^{19}$ and the concept describes the physical-chemical processes that occur naturally in biological material, dead or inactive, derived from biological sources, that allow the passive uptake of toxicants onto its cellular structure. ${ }^{8}$ It is currently accepted that biosorption is as a reversible and fast physical-chemical binding of molecules and/or ions from aqueous solutions onto functional groups present on the surface of biological entities. It can be performed either by inactive or dead biomass, cellular fragments and tissues, or by living cells as an active and metabolism-dependent process. Both mechanisms may overlap, adding additional intricacy to the terminology. $9,18,20$

Biosorption processes occur spontaneously in nature, and they play a critical role in numerous substantial biochemical processes, for example, sorption in soil, sorption on host cells as the first stage in virus replication, or even antigen-antibody 
immune reactions. ${ }^{9}$ The great majority of research reports published in the last decades is essentially related to sorption of metals, namely, heavy metals. Only recently, and due to the increasing number of emerging pollutants, namely, psychiatric drugs and pharmaceutical and personal care products, PPCP, ${ }^{5,21}$ as well as due to their potential hazardous effects on public health, have biosorption processes been employed on nonmetallic systems. ${ }^{22}$

The number of studies related to the ability of different materials of biological origin to decontaminate complex systems is extremely scarce, ${ }^{5,18}$ especially at pilot scale and industrial scale and/or context, thus creating a serious gap between the knowledge acquired and the actual needs of either WWTP and industrial facilities.

2.1.1. Applications and Target Sorbates. The vast majority of biosorption research has been directed toward the entrapment of metal ions and correlated compounds, including metalloids, lanthanides, actinides, and several radioisotopes ions of those molecules. ${ }^{3,9}$ Particulates and colloids have also been studied, as well as organometal (loid) and organic compounds, including dyes. ${ }^{20,23,24}$ Metals and dyes are, in fact, the most thoroughly investigated pollutants/contaminants in this field, and biosorption presents a good potential to remove them as demonstrated by several authors, ${ }^{25-28}$ thus being able to efficiently replace conventional methods. ${ }^{10}$

A vast portion of current research has been carried out on the removal of cations such as lead, cadmium, zinc, copper, mercury, nickel, chromium, and rare earth elements $1,3,20,28,29$ for being key elements in numerous industrial processes with high toxicity. Anions removal has also become an emergent concern in some industries, whose effluents present toxic metals and metalloids such as arsenic, selenium, chromium, molybdenum, and vanadium. ${ }^{3,20}$ In addition, biosorption processes can also be used for subsequent recovery and reuse of metals such as gold, ${ }^{9,19,30}$ thus reducing the economic costs associated with their extraction and disposal as a residue with no increased value.

Organic sorbates such as dyes, phenolics, pesticides, herbicides, hydrocarbons, and polycyclic aromatic hydrocarbons (PAH) may present extreme toxicity, and they persist in the environment. ${ }^{3,9,31-33}$ Kodal and $\mathrm{Akzu}^{34}$ studied the biosorption of Remazol Black B, an anionic dye, onto a dried Rhizopus arrhizus, in the eventual presence of cetyltrimethylammonium bromide, a cationic surfactant. According to the Langmuir model, the highest dye removal capacity was 27.8 $\mathrm{mg}_{\text {dye }} / \mathrm{g}_{\text {dried biomass, }}$ at $\mathrm{pH} 8$, increasing to $500 \mathrm{mg} / \mathrm{g}_{\text {dried biomass }}$ with $200 \mathrm{mg} / \mathrm{L}$ of cetyltrimethylammonium. Ara et al. ${ }^{35}$ used corn cob as biosorbent for the removal of metribuzin, an organic herbicide, and the maximum adsorption value was obtained at $\mathrm{pH} 5\left(Q_{\max }=4.07 \mathrm{mg} / \mathrm{g}\right) .^{32} \mathrm{Al}-$ Zaben and Mekhamer ${ }^{36}$ used a washed and boiled coffee waste to retain 4-chloro-2-methyl phenoxy acetic acid, an organic pesticide, with a maximum capacity adsorption of $340 \mathrm{mg} / \mathrm{g}$. ${ }^{32}$ FloresChaparro et al. ${ }^{33}$ tested three macroalgae (brown, green, and red) as biosorbents for toluene and benzene, two of the most soluble hydrocarbons. Brown macroalgae registered the highest removal capacities, $112 \mathrm{mg} / \mathrm{g}$ and $28 \mathrm{mg} / \mathrm{g}$ for benzene and toluene, respectively. ${ }^{37}$

Another class of molecules also present in the environment have recently received the attention of many researchers: pharmaceuticals compounds. ${ }^{38-41}$ In the last two decades, numerous studies have been conducted to infer about the occurrence, impact, and removal/degradation of pharmaceutical residues from different environmental matrices. ${ }^{42,43}$

Antibiotics, for example, are being held accountable for disturbing the wastewater treatment processes and the microbial ecology of surface water, and it is foreseen that they will have an impact of such order on ecosystems that may destroy their fragile ecological equilibrium. ${ }^{41,44}$ The majority of pharmaceuticals are only partially removed during the biological process in sewage treatment plants, with consequent release into surface water, ${ }^{24,41,44,45}$ becoming thus available to freely react with other chemicals and all forms of living beings.

2.1.2. Effect of $p H$, Organic Matter, and Biosorbents on $P P C P$ Removal Efficiency. Parameters such as $\mathrm{pH}$, natural dissolved organic matter (NDOM), and the type of biosorbent can affect significantly the removal efficiency of pharmaceuticals in water treatment systems (WTS). He et al. ${ }^{46}$ considered the effects of dissolved organic matter (DOM) and nitrification on the biodegradation of several pharmaceuticals (caffeine, metoprolol, propranolol hydrochloride, carbamazepine, naproxen, fenoprofen calcium salts, and ibuprofen) in aerobicenriched cultures from constructed wetlands. Biodegradation of propranolol, carbamazepine, and diclofenac was insignificant $(<15 \%)$; caffeine biodegradation was inhibited by easily biodegradable DOM, whereas DOM enhanced the biodegradation for metoprolol, naproxen, and ibuprofen since it acted as a structural analogue, promoting biomass growth as well as an electron shuttle stimulating the metabolism or cometabolism of such compounds. Nitrification enhanced the biodegradation of naproxen and ibuprofen and mineralization of the seven pharmaceuticals when mixed, as well as of the less biodegradable DOM, which may result from the ammoniaoxidizing bacteria metabolism or from the improved heterotrophic microbial activity. Metoprolol biodegradation was inhibited under nitrification conditions.

The $\mathrm{pH}$ variation is responsible for the protonation/ deprotonation of the sorbents and sorbates, being directly responsible for the polarity of the sorbates and their adsorbability. Generally, at low $\mathrm{pH}$ values, the surface of the sorbents, in particular, oxidic sorbents and, to a lesser extent, carbonaceous ones, becomes positively charged, whereas at high $\mathrm{pH}$ values, it becomes negatively charged. When the operational $\mathrm{pH}$ is above the acid dissociation constant $\left(\mathrm{p} K_{\mathrm{a}}\right)$, the sorbate becomes negatively charged, and sorption is relatively poor, not only as a result of the higher polarity of the charged sorbate species but also due the existing repulsion forces between sorbent and sorbate. When specific conditions occur $\left(\mathrm{pH}_{\mathrm{pzc}}>\mathrm{p} K_{\mathrm{a}}\right.$ for acids and $\mathrm{pH}_{\mathrm{pzc}}<\mathrm{p} K_{\mathrm{a}}$ for bases $)$, the sorbate species and the sorbent surface present opposite charges, attraction forces occur in addition to the van der Waals forces, and maximum sorption is obtained. ${ }^{47}$

The presence of inorganic salts, generally added during primary and/or biological treatments, may also improve the removal of acidic substances due to their precipitation with trivalent cations and subsequent sorption of the precipitated molecules. $^{48}$

2.1.3. Removal of Pharmaceuticals from Aqueous Solutions by Biosorbents. Pharmaceuticals are becoming increasingly problematic contaminants of either surface water and groundwater ${ }^{49}$ and therefore the subject of great concern for researchers. ${ }^{50-52}$ Usually, household pharmaceuticals can enter into the sewage system after human excretion and washing off by tap water via sinks or toilets. ${ }^{53}$ Kümmerer ${ }^{54}$ reported that from $10 \%$ to $90 \%$ of the administered dose of 
Table 1. Removal of Pharmaceutical Drugs by Biosorption

\begin{tabular}{|c|c|c|c|c|c|}
\hline Therapeutic class & Pharmaceutical & Biosorbents & $\begin{array}{c}\text { Initial } \\
\text { concentration }^{a}\end{array}$ & $\begin{array}{l}\text { Removal }(\%) \text { or } \\
\text { uptake }(\mathrm{mg} / \mathrm{g})\end{array}$ & refs \\
\hline \multirow[t]{6}{*}{$\begin{array}{l}\text { Nonsteroidal anti-inflammatory } \\
\text { drugs (NSAID) }\end{array}$} & $\begin{array}{l}\text { Diclofenac sodium } \\
\quad(\text { Na-DCF })\end{array}$ & Sterilized sludge & $5.0 \pm 0.5 \mu \mathrm{g} / \mathrm{L}$ & $40.1 \%$ & 70 \\
\hline & $\begin{array}{l}\text { Diclofenac sodium } \\
\quad(\mathrm{Na}-\mathrm{DCF})\end{array}$ & Isabel grape bagasse & $1-30 \mathrm{mg} / \mathrm{L}$ & $16.4 \%-22.8 \%$ & 71 \\
\hline & Ibuprofen & White-rot fungi Trametes hirsuta & $20-500 \mathrm{ng} / \mathrm{L}$ & $100 \%$ & 72 \\
\hline & Mefenamicacid & White-rot fungi Trametes hirsuta & $20-500 \mathrm{ng} / \mathrm{L}$ & $100 \%$ & 72 \\
\hline & Indomethacin & White-rot fungi Trametes hirsuta & $20-500 \mathrm{ng} / \mathrm{L}$ & $100 \%$ & 72 \\
\hline & Naproxen & White-rot fungi Trametes hirsuta & $20-500 \mathrm{ng} / \mathrm{L}$ & $100 \%$ & 72 \\
\hline \multirow[t]{5}{*}{ Antibiotics } & $\begin{array}{l}\text { Penicillin G } \\
\text { potassium }\end{array}$ & Rhizopus arrhizus and dried activated sludge & $50-1000 \mathrm{mg} / \mathrm{L}$ & $591.8 \mathrm{mg} / \mathrm{g}$ & 24 \\
\hline & Sulfamethyldiazine & Spent mushroom & $0.5-10 \mathrm{mg} / \mathrm{L}$ & $2.1 \mathrm{mg} / \mathrm{g}$ & 73 \\
\hline & Sulfamethazine & Spent mushroom & $0.5-10 \mathrm{mg} / \mathrm{L}$ & $1.8 \mathrm{mg} / \mathrm{g}$ & 73 \\
\hline & Sulfathiazole & Spent mushroom & $0.5-10 \mathrm{mg} / \mathrm{L}$ & $2.3 \mathrm{mg} / \mathrm{g}$ & 73 \\
\hline & Sulfamethoxazole & $\begin{array}{l}\text { Marine algae (Lessonia nigrescens Bory and } \\
\text { Macrocystis integrifolia Bory) }\end{array}$ & n.d. & $73.8 \mathrm{mg} / \mathrm{g}$ & 74 \\
\hline \multirow[t]{2}{*}{ Antibiotics } & Sulfacetamide & $\begin{array}{l}\text { Marine algae (Lessonia nigrescens Bory and } \\
\text { Macrocystis integrifolia Bory) }\end{array}$ & n.d. & $177.9 \mathrm{mg} / \mathrm{g}$ & 74 \\
\hline & Oxytetracycline & Aerobic granular sludge & $5 \mathrm{mg} / \mathrm{L}$ & $91.74 \mathrm{mg} / \mathrm{g}$ & 75 \\
\hline \multirow[t]{3}{*}{ Anticonvulsants/Antiepileptics } & Carbamazepine & Rice straw & $5-50 \mathrm{mg} / \mathrm{L}$ & $\begin{array}{l}60 \%-75 \% \\
\mathrm{q}_{\max }=40 \mathrm{mg} / \mathrm{g}\end{array}$ & 76 \\
\hline & & Activated sludge/Sterilized sludge & $200 \mu \mathrm{g} / \mathrm{L}$ & $8.9 \%$ & 70 \\
\hline & & White-rot fungi Trametes hirsuta & $20-500 \mathrm{ng} / \mathrm{L}$ & $<40 \%$ & 72 \\
\hline
\end{tabular}

pharmaceuticals is excreted in their parent form, while the rest is excreted as metabolites and/or conjugated forms. They are transported into WWTP via sewage pipes, being discharged into surface water, seawater, groundwater, soil, and eventually reaching some drinking water. ${ }^{55}$ Although conventional WWTP can effectively reduce carbon and nitrogen content of raw sewage, ${ }^{56}$ they are impotent at removing pharmaceutical residues. The discharge of WWTP effluents has been identified as the primary source of these contaminants entrance into the aquatic environment. ${ }^{55,57,58}$

In aquatic environments, pharmaceuticals may be toxic to certain aquatic organisms ${ }^{59}$ and may cause adverse effects such as feminization of male fish, ${ }^{60,61}$ alteration of the reproductive function of male and female fishes, ${ }^{62}$ impairment of renal, gill, and liver in fish, ${ }^{63}$ and decrease in plankton diversity. ${ }^{64}$ Even low levels of pharmaceuticals in aquatic environments may have toxic impacts on human health such as degenerative and inflammatory reactions in the liver of humans when exposed to diclofenac. $^{65}$

Some of most popular pharmaceuticals are present in water bodies at concentrations ranging from $\mathrm{ng} / \mathrm{L}$ to $\mu \mathrm{g} / \mathrm{L}^{66,67}$ (SI, Table S1).

According to several articles published between 1997 and $2009,{ }^{68}$ the primary therapeutic classes found in the different environmental matrices are blood lipid-lowering agents, steroid hormones, antibiotics, and nonsteroidal anti-inflammatory drugs. Table 1 presents the updated results relative to the removal of the most significant therapeutic classes of pharmaceutical compounds by biosorption.

Understanding of PPCP physical-chemical properties such as solubility in water $(S)$, Henry coefficient $(H)$, acid dissociation constant $\left(\mathrm{pK}_{\mathrm{a}}\right)$, octanol-water partition coefficient $\left(\mathrm{K}_{\mathrm{OW}}\right)$, sludge-water distribution coefficient $\left(\mathrm{K}_{\mathrm{d}}\right)$, adsorption coefficient $\left(\mathrm{K}_{\mathrm{OC}}\right)$, and degradation rate constants
$\left(\mathrm{K}_{\text {biol }}\right)$ is vital for an accurate analysis of the intricate processes that occur during their course through WWTP. According to Súarez et al., ${ }^{48}$ several scenarios can be predicted in the biological treatment: (i) Substances with low $\mathrm{K}_{\mathrm{d}}$ and high $\mathrm{K}_{\text {biol }}$ are extremely well biodegraded, independently of the solids and hydraulic retention time, SRT, and HRT, respectively. (ii) Substances with high $\mathrm{K}_{\mathrm{d}}$ and low $\mathrm{K}_{\mathrm{biol}}$ are detained in the aeration tank by sorption processes, suffering biological degradation with sufficient SRT. (iii) Substances with medium $\mathrm{K}_{\mathrm{d}}$ and high $\mathrm{K}_{\mathrm{biol}}$ are reasonably degraded, independently of the HRT used, and weakly dependent on SRT. (iv) Substances with low $K_{d}$ and $K_{b i o l}$ are inefficiently eliminated or biodegraded, despite the SRT and HRT used.

PPCP quantification in WWTP should be performed either in liquid or solid phase since a considerable fraction of PPCP, particularly the ones with lipophilic character and thus low water solubility, can be sorbed onto solids. Losses due to air stripping are negligible for estrogens and pharmaceuticals, almost negligible for tonalide and galaxolide, and very significant for celestolide, considering the usual air flow rates employed in traditional activated sludge treatment systems, 5$15 \mathrm{~m}^{3}$ air $/ \mathrm{m}^{3}$ wastewater. ${ }^{48}$ Pharmaceutical compounds such as endocrine-disrupting compounds (EDC) and PPCP with reduced water solubility and high $\mathrm{K}_{\mathrm{OW}}$ or high $\mathrm{K}_{\mathrm{OC}}$ are susceptible to sedimentation or association with biota. ${ }^{69}$ Sorption potential of PPCP is therefore a function of their lipophilic character $\left(\mathrm{K}_{\mathrm{OW}}\right)$ and acidity $\left(\mathrm{p} K_{\mathrm{a}}\right)$.

2.1.3.1. Nonsteroidal Anti-Inflammatory Drugs. Nonsteroidal anti-inflammatory drugs (NSAID) have analgesic and antipyretic properties and have been used in large quantities by humans and animals. ${ }^{77}$ The nonsteroidal antiinflammatory drug diclofenac, DCF (2-(2-(2,6-dichlorophenylamino) phenyl) acetic acid), represents one of the most commonly detected compounds in effluents and surface water 
since it is easily achievable without a prescription and is consumed worldwide. The topical application of DCF is the main source of release into water since it was reported that only $6 \%$ to $7 \%$ is absorbed into the body through the skin, ${ }^{78}$ with the remaining washed off from the skin or clothes. ${ }^{79}$ Diclofenac was recently included by the European Commission on the list of priority substances (European Directive 2013/39/EU) due to its intrinsic toxicity potential and nonbiodegradable behavior. ${ }^{77,80,81}$

Antunes et al. $^{71}$ evaluated the biosorption process of diclofenac sodium (Na-DCF) using Isabel grape (Vitis labrusca and Vitis vinifera) bagasse, describing the kinetics, equilibrium, and thermodynamics of the adsorption process. The removal percentage of Na-DCF ranged from $16.4 \%$ to $22.8 \%$, independently of the initial concentration of the pharmaceutical. The reuse of grape bagasse for the biosorption of Na-DCF had some benefits over commercial-activated carbon due to its low cost since this biomaterial is a waste from a productive process.

Fan et al. $^{70}$ established the contributions of sludge biosorption and biodegradation on the removal of different pharmaceuticals, including Na-DCF. Results of batch adsorption experiments via sterilized sludge showed that the removal efficiency of Na-DCF was $40.1 \%$. The biosorption profile of $\mathrm{Na}-\mathrm{DCF}$ is closed to the total removal profile, so biodegradation is negligible and removal efficiencies are positively correlated with the $\mathrm{K}_{\mathrm{OW}}$ of the different pharmaceuticals tested.

Ibuprofen (IBP) or 2-(4-isobutyl phenyl) propionic acid is the most popular nonsteroidal anti-inflammatory drug resulting from propionic acid, and due to its various applications, a huge amount of IBP is manufactured worldwide. IBP, which was listed by the World Health Organization as one of the "Essential drugs", 82 has been detected in surface water and wastewater in different European countries at the range from $\mathrm{ng} / \mathrm{L}$ to low $\mathrm{mg} / \mathrm{L}$. The ubiquity of IBP is peculiarly alarming due to its potentially detrimental effects on the human endocrine system and on the reproduction of aquatic organisms, even at trace amounts. ${ }^{83}$ Studies have also identified a harmful effect on the central nervous system produced by a degradation product of ibuprofen known as 4-isobutylacetophenone (4-IBAP). ${ }^{84}$

Indomethacin (1-(p-chlorobenzoyl)-2-methyl-5-methoxyindole-3-acetic acid) is a nonsteroid anti-inflammatory drug that is available under about a dozen trademarks and is used for the treatment of intensely painful episodes due to its effectiveness in a short time. ${ }^{85}$ Several works have reported the worldwide detection of indomethacin in surface water and effluents of WWTP. ${ }^{39,86-88}$ Its chronic exposure may cause serious health effects such as endocrine disruption and growth inhibition and may present cytotoxicity toward aquatic animals. ${ }^{89}$

Mefenamic acid (2-[(2,3-dimethylphenyl) amino] benzoic acid) is another NSAID that is taken orally to treat mild to moderate pain, ${ }^{90}$ and it has been detected in sewage effluents as well as in receiving water in different countries. ${ }^{91-96}$

Naproxen (NPX) is a propionic acid derivative of the aryl acetic acid group of NSAID, extensively used to treat moderate pain, osteoporosis, rheumatoid arthritis, menstruation pain, and headaches. In addition, this drug is frequently used in veterinary medicine in considerable quantities. ${ }^{97,98}$ Bioassay tests have revealed that NPX has a chronic toxicity higher than its acute toxicity. Moreover, its photodegradation byproducts are more toxic than NPX itself. ${ }^{99,100}$
The efficiency of the white-rot fungi (WRF) Trametes hirsuta in removing several classes of pharmaceutical drugs, including NSAID (ibuprofen, indomethacin, mefenamic acid, and naproxen), was evaluated by Haroune et al. $^{72}$ at low but environmentally representative concentrations (20-500 ng/ $\mathrm{L})$. These authors compared the importance of biosorption over enzymatic activity on the removal of the selected pharmaceutical active compounds by assessing the performances of living fungi (LF), heat-kill treated fungi (HKF), and biocide-treated fungi (BF). Ibuprofen, indomethacin, mefenamic acid, and naproxen were successfully removed by LF and HKF, but the removal was significantly lower with BF. Biosorption played a key role in the removal process of these compounds, while extracellular enzyme activity had a negligible effect. The higher removal attained with HKF compared with BF could reflect a higher biosorption ability due to improved membrane surface after heat treatment.

2.1.3.2. Antibiotics. The extensive use of antibiotics made them ubiquitious, ${ }^{101}$ and they spread into the environment from different sources such as the production of active ingredients in the pharmaceutical industry, excretion of residues after usage, or from the discarding of unused medicines. After administration to humans and animals, up to $90 \%$ of nonmetabolized antibiotics may be excreted into wastewater, ${ }^{24}$ where they can persist through a complex cycle of transformation and bioaccumulation in the food chain. This may lead to the death of microorganisms performing in wastewater treatment or even to the development of multiresistant strains of bacteria. ${ }^{24}$ The molecules that are highly persistent, and thus more difficult to be removed, degraded, or transformed, present an increasing contamination level in the environment. ${ }^{100}$ Antibiotics are typically detected at $\mathrm{mg} / \mathrm{L}$ levels in hospital effluents and municipal wastewater and at ng/L levels in surface, sea, and groundwater. ${ }^{73,102,103}$

$\beta$-Lactam antibiotics are the largest class of bacterial cell wall synthesis inhibitors, consisting of all antibiotic agents containing a $\beta$-lactam ring in their molecular structures. These antibiotics are among the most widely used due to their broad spectrum. Akzu and Tunç ${ }^{24}$ considered the potential use of dried Rhizopus arrhizus as a substitute for powdered activated carbon, PAC, for the removal of penicillin $G$ from aqueous solutions. The uptake of penicillin $G$ on dried $R$. arrhizus as a function of $\mathrm{pH}$, temperature, and initial antibiotic concentration was evaluated and compared to the one of PAC. The maximum uptake capacity is $591.8 \mathrm{mg} / \mathrm{g}$ for dried $R$. arrhizus, while the uptake of PAC is $463.0 \mathrm{mg} / \mathrm{g}$ at $35^{\circ} \mathrm{C}$.

Sulfonamide antibiotics (sulfas) are a group of synthetic medicines that contain the sulfonamide chemical group, being used in human therapy, livestock production, and aquaculture. Zhou et al. ${ }^{73}$ reported the potential use of spent mushroom substrates, which is a readily available agricultural waste, for the biosorption of sulfas from water in a batch process. The maximum adsorption capacities reported were 2.1, 1.8, 2.3, and $2.2 \mathrm{mg} / \mathrm{g}$ at $288 \mathrm{~K}$ for sulfamethyldiazine, sulfamethazine, sulfathiazole, and sulfamethoxazole, respectively. Spent mushroom substrates are low-cost and effective adsorbents to remove sulfas from water while reducing agricultural waste, thereby improving and preserving the environment. Likewise, Navarro et al. ${ }^{74}$ investigated the biosorption of two sulfonamides, sulfamethoxazole and sulfacetamide, by marine algae: Lessonia nigrescens Bory (L13) and Macrocystis integrifolia Bory (S12). Both marine seaweed have high sorption capacity, which can be related to the presence of surface functional 
groups such as fucoidan and alginate, that have high electron density. ${ }^{104}$ Navarro et al. $^{74}$ reported that the maximum adsorption capacity of sulfamethoxazole, $73.8 \mathrm{mg} / \mathrm{g}$, was reached by L13, whereas the higher adsorption capacity for sulfacetamide, $177.94 \mathrm{mg} / \mathrm{g}$, was attained by $\mathrm{S} 12$.

Tetracyclines are considered one of the cheapest and most used classes of prime antibiotics throughout the world. Mihciokur and Oguz ${ }^{75}$ studied the biosorption of oxytetracycline, a wide spectrum antibiotic, by an aerobic granular sludge. They fed a sequential batch reactor with artificial wastewater and found the optimum operating conditions. A maximum adsorption capacity of $91.74 \mathrm{mg} / \mathrm{g}$ was established at $\mathrm{pH} 6$.

2.1.3.3. Anticonvulsants/Antiepileptics. Antiepileptics and anticonvulsants are central nervous system (CNS) medicines that help to reduce the unnatural firings of nerves in the CNS and in the brain. ${ }^{5,105}$ Among this class of pharmaceuticals, carbamazepine (5H-dibenzo[b,f]azepine-5-carboxamide) is the most frequently detected pharmaceutical in various water bodies. ${ }^{106-108}$ Clara et al. ${ }^{109}$ classified carbamazepine as a suitable marker for anthropogenic influences in the aquatic environment. Carbamazepine works by reducing abnormal electrical activity in the brain and is commonly used in the treatment of epilepsy and neuropathic pain, as well as mental illnesses such as of schizophrenia and bipolar disorder. ${ }^{106,110}$ Classified as an emerging recalcitrant organic pollutant, carbamazepine is also found to be extremely persistent during chlorination procedures usually employed in water treatment systems. ${ }^{111,112}$ Carbamazepine is hardly biodegraded or adsorbed onto solid surfaces which results in a relatively low removal performance, mostly below $10 \%$, through conventional WWTP. ${ }^{113-115}$ Studies in North America and in Europe have revealed that carbamazepine is one of the pharmaceuticals most commonly detected in river water, WWTP effluents, final sewage effluents, surface water, drinking water, and groundwater. $5,106,116$ This scenario can be aggravated if metabolites are also present since besides of being able to persist in the environment for long periods of time, their effects and impact on living beings and on ecosystems are little known.

The efficiency of biosorption of carbamazepine on white-rot fungi (WRF) Trametes hirsuta was evaluated by Haroune et al. ${ }^{72}$ Contributions of biosorption over enzymatic activity were assessed, comparing the performances of living fungi (LF), heat-kill treated fungi (HKF), and biocide-treated fungi (BF). The removal of carbamazepine is very effective and similar comparing LF and HKF, but it is significantly weaker with BF. The similar performances of LF and HKF are related to the limited effect of the extracellular enzyme LAC on the removal. The higher removal observed with $\mathrm{HKB}$ compared to $\mathrm{BF}$ is probably related to an improved membrane surface after heatinduced membrane breakdown.

Fan et al. ${ }^{70}$ reported the contributions of sludge biosorption and biodegradation on the removal of different pharmaceuticals including carbamazepine by operating a submerged membrane bioreactor using sterilized sludge and activated sludge. The total removal efficiency of carbamazepine was only $8.9 \%$, and for that reason, neither sludge adsorption nor biodegradation was effective in those circumstances. Liu et al. ${ }^{76}$ evaluated the removal of carbamazepine by the agricultural waste rice straw biosorbent (RSB) and reported that the removal efficiency of carbamazepine was enhanced with the increase in RSB dosage without $\mathrm{pH}$ control. The maximum measured uptake of carbamazepine was $40.0 \mathrm{mg} / \mathrm{g}$.
2.2. Biodegradation. Biodegradation is the transformation of organic substances into smaller and simpler molecules by the action of enzymes naturally produced by living microbial consortia. Biodegradation processes can either be complete, with mineralization of the substrate into the final product $\mathrm{CO}_{2}$, or it can be incomplete, with the substrate transformation into intermediates/metabolites. Although many microorganisms are able to adapt to new environmental conditions, eventually degrading organic compounds of anthropogenic origin in the process, ${ }^{6,117}$ not all hazardous compounds are biodegradable, limiting the application of biodegradation. This advantageous ability to degrade complex and hazardous compounds is of crucial importance in the case of pharmaceuticals since it may lead to the development of resistant or even multiresistant microbial species toward one or more pharmaceuticals. ${ }^{118-120}$

It is important to highlight that the majority of the biodegradation studies conducted to date have been focused on the evaluation and optimization of the degradation capacity of microbial species or microbial consortia toward a specific organic contaminant with no special attention to the metabolites formed or to their potential toxicity and fate. $^{22,118}$ This is quite relevant since the degradation of pharmaceutical compounds usually leads to the production of more polar, soluble, and therefore more mobile metabolites. ${ }^{118}$

2.2.1. Nonsteroid and Anti-Inflammatory Drugs. According to recent reports on its ecotoxicity, DCF exposure was identified as the main and possibly the only cause responsible for the fast decline on the Gyps vultures population across the Indian subcontinent. ${ }^{121}$ DCF exposure up to $0.1 \mu \mathrm{g} / \mathrm{L}$ was found to affect the biochemical processes of duckweed plants, $^{122}$ whereas contamination up to $0.2 \mu \mathrm{g} / \mathrm{kg}$ has a detrimental impact on freshwater fishes. ${ }^{123}$ At high concentrations $(50-100 \mathrm{mg} / \mathrm{L})$, DCF inhibits the DNA synthesis of Gram-positive and Gram-negative bacteria and thus their growth.

Moreira et al. ${ }^{124}$ evaluated the capacity of Labrys portucalensis $\mathrm{F} 11$ to biodegrade DCF in aqueous solutions (1.7-34.0 $\mu \mathrm{M})$, eventually supplemented with $5.9 \mathrm{mM}$ of sodium acetate. Here, $70 \%$ biodegradation of DCF was reached within 30 days in assays with DCF as the only carbon source, whereas complete degradation was reached via cometabolism with sodium acetate (6 and 25 days for initial concentrations of DCF equal to 1.7 and $34.0 \mu \mathrm{M}$, respectively). In this evaluation, numerous metabolites were detected through UPLC-QTOF/MS/MS, and the chemical structure of 12 of them was proposed. At the end of the assays, stoichiometric liberation of chlorine was observed, and no metabolites were detected, thus suggesting the complete biodegradation of DCF by the bacteria Labrys portucalensis F11. These results are of extreme relevance as they constitute the first report on the identification of the conjugated metabolites of the bacterial sulfonation reaction with DCF, allowing the assessment of their effects and impact on the environment and on living beings. This is also the first report to point out the complete degradation of DCF by a single bacterial strain culture previously isolated from the environment, proving once again the extraordinary capacity of microorganisms to degrade complex and hazardous substances.

Paje et al. ${ }^{117}$ reported that lotic biofilms composed of algal and bacterial species lost $70 \%$ of their entire initial biomass when exposed to $100 \mu \mathrm{g} / \mathrm{L}$ of DCF for 4 weeks. Some of Cytophaga species (a Gram-negative, gliding, and rod-shaped bacterium usually found in soil) presented microbial viability 
Table 2. Microorganisms Identified as Efficient Degraders of Acetaminophen as Sole Carbon Source ${ }^{a}$

\begin{tabular}{|c|c|c|c|c|}
\hline Microorganism & Isolated from & Concentration & Biodegradation & refs \\
\hline Burkholderia sp. AK-5 & Rice field soil contaminated with 4-aminophenol & $2.14 \mathrm{~g} / \mathrm{L}$ & $\pm 99 \%(15 \mathrm{~h})$ & 137 \\
\hline Cupriavidus necator F1 & Activated sludge & $1 \mathrm{~g} / \mathrm{L}$ & $\pm 96 \%(20 \mathrm{~h})$ & 138 \\
\hline Delftia tsuruhatensis & Biomass from a bioreactor membrane & $100 \mathrm{mg} / \mathrm{L}$ & $\pm 97 \%(48 \mathrm{~h})$ & 135 \\
\hline Penicillium sp. & Paracetamol acidic solution & $0.01 \%(\mathrm{w} / \mathrm{v})$ & $\pm 98 \%(36 \mathrm{~h})$ & 139 \\
\hline Pseudomonas aeruginosa & Biomass from a bioreactor membrane & $16 \mathrm{mg} / \mathrm{L}$ & $\pm 40 \%(48 \mathrm{~h})$ & 135 \\
\hline Pseudomonas sp. $\mathrm{f} 2$ & Acetaminophen degrading aerobic aggregate & $2.50 \mathrm{~g} / \mathrm{L}$ & $100 \%(70 \mathrm{~h})$ & 136 \\
\hline Pseudomonas sp. fg2 & Acetaminophen degrading aerobic aggregate & $2 \mathrm{~g} / \mathrm{L}$ & $100 \%(45 \mathrm{~h})$ & 136 \\
\hline Pseudomonas sp. ST-4 & Activated sludge (4-aminophenol as substrate) & $200 \mathrm{ppm}$ & $\pm 80 \%(72 \mathrm{~h})$ & 140 \\
\hline Pseudomonas sp. AP-3 & Activated sludge (2-aminophenol as substrate) & $340 \mathrm{ppm}$ & $\pm 70 \%(48 \mathrm{~h})$ & 141 \\
\hline Stenotraphomonas sp. $\mathrm{f} 1$ & Acetaminophen degrading aerobic aggregate & $400 \mathrm{mg} / \mathrm{L}$ & $100 \%(116 \mathrm{~h})$ & 136 \\
\hline
\end{tabular}

after a 6 week period of acclimatization and was able to biodegrade up to $97 \%$ of DCF $(100 \mu \mathrm{g} / \mathrm{L})$ after 10 weeks of its addition. These results demonstrate the adaptive and the biodegradative capacity of the microbial consortium toward DCF.

Ibuprofen is a chiral molecule, and it has two different isomers that can be detected in the environmental matrices: $\mathrm{S}-(+)$-ibuprofen and $\mathrm{R}-(-)$-ibuprofen, respectively, the pharmacologically active and the inactive isomers. ${ }^{6}$ Ibuprofen metabolites are also chiral molecules and present a higher toxic profile than the parent compound. ${ }^{125}$ The biodegradation of IBP $(87 \%)$ in the laboratory using river water and sediment microcosms $(20 \mu \mathrm{g} / \mathrm{L})^{126}$ or riverine microbial biofilms (100 $\mu \mathrm{g} / \mathrm{L})^{127}$ was established, respectively, after a few hours and between 4 and 8 days of its addition. Hydroxyl ibuprofen, one of three metabolites of IBP, was also detected with removal percentages between $89 \%$ and $100 \%$.

Marco-Urrea et al. ${ }^{128}$ tested several white-rot fungi ( Trametes versicolor, Irpex lacteus, Ganoderma lucidum, and Phanerochaete chrysosporium) and demonstrated the ability of these microorganisms to degrade several pharmaceuticals, namely, IBP in high concentrations $(10 \mathrm{mg} / \mathrm{L})$ in a 7 days period. T. versicolor was found to degrade IBP at a very early stage of the process into two hydroxylated metabolites, 1hydroxy ibuprofen and 2-hydroxy ibuprofen, that are posteriorly degraded to 1,2-dihydroxy ibuprofen, a metabolite that has not been detected to date in biological systems. Assays conducted by Chen and Rosazza ${ }^{126}$ with an alpha-Proteobacteria Sphingomonas sp., previously isolated from an enriched culture with IBP $(500 \mathrm{mg} / \mathrm{L})$ using an inoculum from a WWTP, was able to biodegrade IBP.

Although the information on the effects of ibuprofen on microorganisms is scarce, significant antifungal activity ${ }^{129}$ and antibacterial activity against Gram-positive bacteria has been reported. ${ }^{130}$ Lawrence et al. ${ }^{131}$ tested a riverine biofilm community, originated from rotating annular bioreactors, to appraise the impact of $10 \mu \mathrm{g} / \mathrm{L}$ of IBP among other pharmaceuticals, and they observed that IBP exposure reduced the bacterial biomass, and gamma-Proteobacteria and Grampositive Firmicutes populations decreased significantly, whereas Cytophaga-Flavobacteria alpha- and beta-Proteobacteria and SRB385 (sulfate-reducing bacteria) populations increased, indicating that these microorganisms may play a role in IBP biodegradation. Quintana et al. ${ }^{132}$ revealed the inability of a fresh sludge from a membrane bioreactor to biodegrade IBP as a sole carbon source under aerobic conditions and after 28 days of contact. However, when powdered milk was added acting as an additional carbon source, co-metabolism of IBP was complete within 22 days, indicating that IBP can be easily biodegraded in the presence of others carbons sources. The ability of these microorganisms to completely biodegrade IBF in the presence of additional carbon sources is extremely positive since it represents a real situation (effluents are usually a cocktail of organic and inorganic substances) and highlights the remarkable ability of microorganisms to degrade complex molecules. Naproxen is usually found as a microcontaminant of rivers and of groundwater from aquifers recharged with domestic water. ${ }^{6}$ Wojcieszynska et al. ${ }^{133}$ proved the ability of a Stenotrophomonas maltophila KB2 strain, a gammaProteobacteria, to biodegrade within 35 days $28 \%$ of the initial concentration of the naproxen used $\left(6 \mathrm{mg} / \mathrm{L}, 30{ }^{\circ} \mathrm{C}\right)$. Moreover, when an additional carbon source (glucose or phenol) was added, the naproxen biodegradation capacity of $S$. maltophila KB2 increases significantly (78\% and $40 \%$, respectively). T. versicolor was found to degrade naproxen $(55 \mu \mathrm{g} / \mathrm{L}$ and $10 \mathrm{mg} / \mathrm{L})$ a few hours after its addition. RodarteMorales et al. ${ }^{134}$ reported the ability of Phanerochaete chrysosporium to completely biodegrade naproxen $(1 \mathrm{mg} / \mathrm{L})$ within 4 days and by Bjerkandera sp. R1 and by Bjerkandera adusta within 7 days.

The majority of the biodegradation studies conducted with naproxen revealed that this drug is not an intrinsically persistent pharmaceutical and is biodegradable in aerobic conditions. However, it is usually found in surface water at higher concentrations than the intrinsically persistent pharmaceuticals. In recent publications, the detrimental impact of naproxen $(100 \mu \mathrm{g} / \mathrm{L})$ on the microbial community of surface water was visible only $3 \mathrm{~h}$ after its addition: a significant decrease on the microbial cell viability and on the betaProteobacteria group, namely, the ammonia oxidizing bacteria (AOB), which are involved in the nitrogen cycle.

2.2.2. Analgesics and Antipyretics. Acetaminophen, usually known as paracetamol, is the most commonly used over-thecounter painkiller, and it acts by inhibiting the cyclooxygenase isozyme COX-3 activity. Recent reports have detected acetaminophen in groundwater at concentrations up to 120 $\mu \mathrm{g} / \mathrm{L}$. According to $\mathrm{Wu}$ et $\mathrm{al}^{2}{ }^{2}$ several bacterial and fungal species have been identified as efficient acetaminophen degraders (Table 2) and producers of easily metabolized intermediates.

Gusseme et al. ${ }^{135}$ reported the isolation of two acetaminophen-degrading bacteria strains from a membrane bioreactor biomass, identified as Delftia tsuruhatensis and Pseudomonas aeruginosa. Zhang et al. ${ }^{136}$ were able to isolate three bacterial strains from an acetaminophen-degrading aerobic aggregate using acetaminophen $(0.4,2$, and $2.50 \mathrm{~g} / \mathrm{L}$, respectively) as the 
Table 3. Bacteria Identified as Carbamazepine Biodegraders ${ }^{a}$

\begin{tabular}{llll}
\multicolumn{1}{c}{ Microorganisms } & Concentration & Biodegradation & \multicolumn{1}{c}{ Enzyme(s) involved } \\
Streptomyces MIUG 4.89 & $200 \mu \mathrm{g} / \mathrm{L}$ & $3 \%(7 \mathrm{~d})$ & - \\
Streptomyces MIUG 4.89 & $200 \mu \mathrm{g} / \mathrm{L}$ & $35 \%(7 \mathrm{~d})$ & Laccase, phenoloxidase \\
Streptomyces SNA & $200 \mu \mathrm{g} / \mathrm{L}$ & $30 \%(7 \mathrm{~d})$ & Laccase \\
Rhodococcus rhodococcus & $9500 \mu \mathrm{g} / \mathrm{L}$ & $15 \%(7 \mathrm{~d})$ & - \\
Pseudomonas CBZ-4 & $9500 \mu \mathrm{g} / \mathrm{L}$ & $46.6 \%(144 \mathrm{~h})$ & - \\
Acetinobacter US1 & $100 \mu \mathrm{g} / \mathrm{L}$ & $60 \%(12 \mathrm{~d})$ & - \\
Bacillus halodurans & $100 \mu \mathrm{g} / \mathrm{L}$ & $60 \%(12 \mathrm{~d})$ & - \\
Micrococcus SBS-8 & $100 \mu \mathrm{g} / \mathrm{L}$ & $60 \%(12 \mathrm{~d})$ & Biphenyl dioxygenase, dihydrodiol dehydrogenase \\
Pseudomonas putida & $100 \mu \mathrm{g} / \mathrm{L}$ & $60 \%(12 \mathrm{~d})$ & \\
Paraburkholderia xenovorans LB400 & $10,000 \mu \mathrm{g} / \mathrm{L}$ & $100 \%(24 \mathrm{~h})$ & \\
${ }^{a}$ Adapted from Nasir et al. ${ }^{145}$ and Wu et al ${ }^{147}$. & &
\end{tabular}

sole carbon, nitrogen, and energy sources. These strains were identified as belonging to the genera Stenotrophomonas and Pseudomonas. The Stenotrophomonas species did not include, until recently, any known acetaminophen degraders in the group. The combination of the three bacterial strains was required for complete biodegradation and mineralization of acetaminophen, revealing a potential complementary interaction between these isolates. The ability of Pseudomonas sp. to use aromatic compounds as a carbon energy source under aerobic conditions makes it an attractive microorganism to be used in waste treatment application, where cocktails of organic compounds are present at variable concentrations.

Experiments conducted by Alvarino et al. ${ }^{142}$ aiming to assess the effect of acetaminophen and doxycycline, an antibiotic (50-1000 $\mathrm{mg} / \mathrm{L})$, on anammox, a microbial anaerobic ammonium oxidation reaction that oxidizes ammonium to dinitrogen gas under anoxic conditions and using nitrite as electron acceptor, revealed the anammox bacteria inhibition and the nitrification and denitrification inhibition $(\geq 25 \%)$ in the presence of acetaminophen $(\geq 250 \mathrm{mg} / \mathrm{L})$. Li et al. ${ }^{143}$ evaluated through the use of ${ }^{14} \mathrm{C}$-labeling and LC-MS/MS techniques, the dissipation routes, and biodegradation pathways of acetaminophen $(4 \mu \mathrm{g} / \mathrm{g})$ in soil subjected to different treatments (nonsterilized, sterilized, and biosolid-amended soil). After a 120 day experiment under aerobic conditions, up to $17 \%$ of ${ }^{14} \mathrm{C}$-acetaminophen was mineralized, and mineralization was significantly inhibited after soil sterilization or amendment with biosolids due to the nonextractability of ${ }^{14} \mathrm{C}$-residues $\left(73.4 \%-93.3 \%\right.$ of the initial amount of ${ }^{14} \mathrm{C}$ acetaminophen used). Eight metabolites were identified in this study: hydroquinone, 3-hydroxyacetaminophen, 1,4-benzoquinone, 1,4-dimethoxybenzene, $N$-acetyl- $p$-benzoquinone, imine4-methoxyphenol, 2-hexenoic acid, and $p$-acetanisidide. These authors also observed that either the acetaminophen mineralization or its conversion to bound residues are rapid, suggesting that soil is promptly detoxified, minimizing the potential for off-site transport.

2.2.3. Antibiotics. The discharge of antibiotics or other antimicrobial substances into the environment seriously compromise public health by promoting the development of mechanisms of bacterial resistance particularly by the species considered as pathogens since the genes conferring resistance are usually amenable to horizontal transfer. Furthermore, it may lead to the disappearance of organic matter or inhibition of chemical microbial degraders in WWTP, soil, and water ecosystems. $^{6}$

Wang et al. ${ }^{120}$ evaluated the biodegradation capacity of a sulfamethoxazole (SMX) degrading strain Acinetobacter sp. toward several pharmaceuticals, including sulfamethazine (SMT, $30 \mathrm{mg} / \mathrm{L}$ ), sulfadiazine (SD, $30 \mathrm{mg} / \mathrm{L})$, triclosan (TCS, $2 \mathrm{mg} / \mathrm{L}$ ), and thimethoprim (THM, $2 \mathrm{mg} / \mathrm{L}$ ). Although Acinetobacter sp. presented different mineralization efficiencies toward SMT (20.5\%), SD (17.5\%), and SMX (98.8\%), complete biodegradation was attained for these compounds. For TCS and THM, no biodegradation was observed. The biodegradation capacity of Acinetobacter toward TCS and THM in the presence of SMX was not improved. On the other hand, the presence of THM decreased SMX biodegradation, whereas the presence of TCS could completely inhibit SMX degradation.

The biodegradation of ciprofloxacin (CIP, $5 \mathrm{mg} / \mathrm{L}$ ), ofloxacin (OFL, $5 \mathrm{mg} / \mathrm{L}$ ), norfloxacin (NOR, $5 \mathrm{mg} / \mathrm{L}$ ), and enrofloxacin (ENR, $5 \mathrm{mg} / \mathrm{L}$ ) by Thermus sp. was assessed by Pan et al., ${ }^{144}$ who isolated it from pharmaceutical sludge and acclimatized it posteriorly with CIP (5-20 mg/L) for several weeks. The optimal $\mathrm{pH}$ and temperature for CIP degradation were 6.5 and $70{ }^{\circ} \mathrm{C}$, respectively, for $55 \%$ degradation. Biodegradation of $63 \%, 70 \%$, and $74 \%$ were attained, respectively, for OFL, NOR, and ENR after $72 \mathrm{~h}$ of exposure. The versatility of Thermus sp. toward different types of fluoroquinolones may be explained by their similar structure, while the different biodegradation performance is a reflex of different toxicity profiles.

2.2.4. Anticonvulsants/Antiepileptics. Carbamazepine is an antiepileptic compound, frequently detected in surface water, wastewater, and occasionally in groundwater, ${ }^{6,145}$ with high persistence in the environment and severe detrimental impact on the ecosystem dynamics. ${ }^{145}$

Bessa et al. ${ }^{146}$ evaluated the biodegradation capacity of two bacteria strains previously isolated from a municipal WWTP (Ponte de Moreira, Maia, Portugal) and enriched in minimal salt medium contaminated with carbamazepine $(24 \mathrm{mg} / \mathrm{L})$ for 6.5 months to biodegrade carbamazepine $(10 \mathrm{mg} / \mathrm{L})$ as the sole carbon source. The bacteria were identified as Starkeya sp. $\mathrm{C} 11$ and Rhizobium sp. C12 and showed reduced biodegradation capacity (30\%) regardless of the acetate supplement. According to Nasir et al. ${ }^{145}$ and $\mathrm{Wu}$ et al., ${ }^{147}$ studies on carbamazepine biodegradation by bacterial species are limited, summarized in Table 3.

Xiong et al. ${ }^{148}$ assessed the biodegradation capacity of Chlamydomonas mexicana and Scenedesmus obliquus toward carbamazepine $(0-100 \mathrm{mg} / \mathrm{L})$, as well as its toxicity and cellular stresses resulting from its exposure.

The results revealed for both algae a decrease in cell growth with an increase in carbamazepine concentration (97\% and $30 \%$ growth inhibition for S. obliquus and C. mexicana, 
Table 4. Fungi Identified as Carbamazepine Biodegraders ${ }^{a}$

\begin{tabular}{|c|c|c|c|}
\hline Fungi & Concentration & Biodegradation & Enzyme(s) involved \\
\hline T. harzianum & $4 \mu \mathrm{g} / \mathrm{L}$ & $72 \%(15 \mathrm{~d})$ & Cytochrom e P450 \\
\hline P. ostreatus & $4 \mu \mathrm{g} / \mathrm{L}$ & $68 \%(15 d)$ & Cytochrom e P450 \\
\hline P. ostreatus PC9 & $8740 \mu \mathrm{g} / \mathrm{L}$ & $99 \%(25 \mathrm{~d})$ & Cytochrom e P450, epoxidehydrolase \\
\hline T. versicolor (ATCC 42530) & $20 \mu \mathrm{g} / \mathrm{L}$ & $57 \%(72 \mathrm{~h})$ & Laccase \\
\hline \multirow[t]{3}{*}{ T. versicolor (ATCC 42530) } & $9000 \mu \mathrm{g} / \mathrm{L}$ & $94 \%(6 \mathrm{~d})$ & Laccase \\
\hline & $50 \mu \mathrm{g} / \mathrm{L}$ & $61 \%(7 d)$ & Laccase \\
\hline & $200 \mu \mathrm{g} / \mathrm{L}$ & $54 \%(15 \mathrm{~d})$ & Laccase \\
\hline \multirow[t]{2}{*}{ T. versicolor (immobilized laccase on $\mathrm{TiO}_{2}$ nanoparticles) } & $4.73 \mu \mathrm{g} / \mathrm{L}$ & $40 \%(96 \mathrm{~h})$ & Laccase \\
\hline & $4.73 \mu \mathrm{g} / \mathrm{L}$ & $68 \%(96 \mathrm{~h})$ & Laccase \\
\hline T. versicolor NRRL 66313 & $350 \mu \mathrm{g} / \mathrm{L}$ & $60 \%(8 d)$ & Laccase, lignin and manganese peroxidase \\
\hline T. versicolor (ATCC 7731) & $930 \mu \mathrm{g} / \mathrm{L}$ & $10 \%(22 \mathrm{~h})$ & Laccase \\
\hline Cunninghamella elegans (ATCC 9254) & $0.24 \mu \mathrm{g} / \mathrm{L}$ & $43 \%(25 \mathrm{~d})$ & - \\
\hline Umbelopsis ramanniana $\mathrm{R}-56$ & $0.24 \mu \mathrm{g} / \mathrm{L}$ & $26 \%(25 d)$ & - \\
\hline Phanerochaete chrysosporium BKM F-1767 & $5000-1000 \mu \mathrm{g} / \mathrm{L}$ & $60 \%-80 \%(100 \mathrm{~d})$ & Lignin and manganese peroxidase \\
\hline \multirow[t]{2}{*}{ Phanerochaete chrysosporium BKM F-1767 (immobilized) } & $1000 \mu \mathrm{g} / \mathrm{L}$ & $80 \%(165 d)$ & Manganese peroxidase \\
\hline & $1000 \mu \mathrm{g} / \mathrm{L}$ & $>90 \%(160 \mathrm{~d})$ & Lignin and manganese peroxidase \\
\hline Aspergillus niger & $11,400 \mu \mathrm{g} / \mathrm{L}$ & $9 \%(7 \mathrm{~d})$ & - \\
\hline Adapted from Nasir et al. ${ }^{145}$ and $\mathrm{Wu}$ et al. ${ }^{147}$ & & & \\
\hline
\end{tabular}

respectively, for an initial concentration of $200 \mathrm{mg} / \mathrm{L}$ ). Biochemical characteristics such as enzyme activities (CAT and SOD), total chlorophyll, and carotenoid contents were affected for both algae when a high concentration of carbamazepine was used. The total chlorophyll and carotenoid content as well as the CAT and SOD activity increased, suggesting the activation of a protective mechanism against external stress conditions induced by carbamazepine. A maximum biodegradation of $35 \%$ and $28 \%$ were, respectively, achieved for C. mexicana and for S. obliquus. Two metabolites were identified by UPLC-MS: 10,11-dihydro-10,11-expoxy carbamazepine and n-hydroxy-carbamazepine.

According to Nasir et al., ${ }^{145}$ the most common fungi used to biodegrade carbamazepine are Trichoderma harzianum, Pleurotus ostreatus (normal strain and strain AC9), immobilized T. versicolor, T. versicolor (ATCC 42530, ATCC 7731, and NRRL 66313), Aspergillus niger, Cunninghamella elegans (ATCC 9254), Umbelopsis ramanniana R-56, and Phanerochaete chrysosporium (mobilized strain F-1767 and immobilized strain F-1767) Table 4.

2.2.5. Antidepressants. According to a survey performed by the Organization for Economic Cooperation and Development (OECD) in 25 countries regarding the use of antidepressants, these are among the group of pharmaceuticals most prescribed worldwide, and their consumption has increased exponentially between 2000 and 2010. Their use in Germany has risen 46\%, whereas in Spain and Portugal this increase was about $20 \%$. Although the United States is not included in the OECD analysis, it is believed that $11 \%$ of Americans over the age of 12 take antidepressants. Even if the obtained data may not be as accurate as it should, since the popularity of antidepressants in a given country is the result of a complex mixture of depression ratios, wealth, health coverage, stigma, and availability of treatment, ${ }^{149}$ this tendency is quite worrying, not only due to the reasons underlying the prescription of such medicines but also because of the impact that these huge amounts of drugs and consequently their derivates will exert, at short and long term, on the ecosystems.

A group of antidepressants that has been raising serious concern due to its wide use and mode of action, i.e., modulation of the levels of the neurotransmitter serotonin, is the selective serotonin reuptake inhibitors (SSRI). Despite their hazardous impact on the ecosystem, the number of environmental studies concerning fluoxetine persistence and biodegradation by natural microbial communities is extremely scarce. Kwon and Armbrust ${ }^{150}$ evaluated the laboratory persistence and fate of fluoxetine in aquatic environments, including experiments performed with several distinct aqueous solutions, water/sediment systems, and activated sludgeamended media in light and dark environments. With the exception of synthetic humic water $(\mathrm{pH} 7)$, fluoxetine was found to be hydrolytically and photolytically stable in all the experiments for over a period of 30 days. The biodegradation rate increases sharply in the experiments conducted with synthetic humic water ( $\mathrm{pH} 7)$ : approximately 13-fold in comparison with buffered solutions at the same $\mathrm{pH}$. In water/ sediments, fluoxetine was found to rapidly dissipate from the aqueous phase due to sediments distribution. The dissipation rate from the aqueous phase was identical between light and dark environments, suggesting a low input of photodegradation processes to fluoxetine dissipation. A photoproduct was detected in the assays conducted with synthetic humic water and identified as norfluoxetine formed by demethylation of fluoxetine. These results reinforced the thesis regarding fluoxetine persistence and resilience to hydrolysis, photolysis, and microbial degradation and its fast removal from surface water due sediments adsorption.

Moreira et al. ${ }^{151}$ studied the enantioselective biodegradation of racemic fluoxetine and of its enantiomers by Labrys portucalensis strain $\mathrm{F} 11$. When $2 \mu \mathrm{M}$ of racemic fluoxetine was used as the only carbon source, total biodegradation of both molecules was obtained within 30 days, with stoichio- 
metric release of fluoride. This was not observed when 4 and 9 $\mu \mathrm{M}$ of racemic fluoxetine were used. When acetate is present, acting as a supplementary carbon source at $4,9,21$, and $25 \mu \mathrm{M}$ of racemic fluoxetine, (S)-fluoxetine, or (R)-fluoxetine, the two enantiomers suffered complete biodegradation. For superior concentrations of racemic fluoxetine ( 45 and $89 \mu \mathrm{M})$, partial biodegradation was obtained. Preferential biodegradation of (R)-fluoxetine was observed for all the experiments.

Velázquez and Nacheva ${ }^{152}$ evaluated the biodegradation capacity of a nitrite-oxidizing consortium, an ammoniumnitrite-oxidizing consortium, and a heterotrophic biomass toward pharmaceuticals, including fluoxetine, in batch tests with different retention times. The heterotrophic and the ammonium-nitrite-oxidizing consortia presented the highest biodegradation capacity, reaching, respectively, $85 \%$ and $79 \%$ biodegradation, whereas the nitrite-oxidizing consortium was only capable of biodegrading $48 \%$ of fluoxetine $(1 \mathrm{~g} / \mathrm{L})$. The assessment of fluoxetine in the dissolved phase and in the biomass indicated that biodegradation was the major removal mechanism ( $86 \%$ to $94 \%)$ and that biosorption contributed only with $6 \%$ to $14 \%$ to its removal.

2.2.6. Blood Lipid Regulators. The growing number of cardiovascular diseases as a consequence of high cholesterol ${ }^{153}$ has triggered an enormous increase in the volume of cholesterol-lowering substances prescribed. Gemfibrozil and clofibric acid, the primary intermediate of clofibrate lipid regulators, are the main common blood lipid regulators and respective metabolites found in European wastewater. Clofibric acid is accounted for as one of the most persistent metabolites with an estimated persistence in the environment of 21 years. ${ }^{105}$ Buser et al. ${ }^{154}$ detected the presence of clofibric acid in the North Sea at concentrations up to $7.8 \mathrm{ng} / \mathrm{L}$. Quintana et al. ${ }^{132}$ proved bioreactors to be inefficient for the degradation of clofibric acid present in municipal wastewater, while Zhou et al. $^{155}$ demonstrated that aerobic sequencing batch reactors could promote the co-metabolical degradation of clofibric acid by a bacterial consortium dominated AOB. This bacterial consortium was first acclimatized with chlorinated aromatic molecules and then used as an inoculum in the batch reactors experiments. Still, recent studies reported concentrations of clofibric acid in surface waters higher than $240 \mathrm{ng} / \mathrm{L}$. $^{156}$

Although gemfibrozil was not classified by the Agency for Research on Cancer regarding its carcinogenicity toward humans, recent reports have proven its toxicity and carcinogenic properties toward several organisms such as rodents (induction of peroxisome proliferation) and eels (induction of liver cancer), as well as its harmful effects on nontargets aquatic organisms. Despite being considered as a nonbiodegradable and a moderately to highly persistent pharmaceutical, ${ }^{94,157,158}$ recent studies have demonstrated the ability of different microbial species to biodegrade gemfibrozil, aiming at its removal from aqueous matrices. ${ }^{6}$ Lin et al. ${ }^{127}$ observed that gemfibrozil degradation was achieved with a halflife inferior than $24 \mathrm{~h}$, whereas Zhou et al. ${ }^{155}$ were able to isolate a strain of Bacillus sp. from the sludge of a WWTP, able to quickly and efficiently degrade gemfibrozil in liquid culture at concentrations below $60 \mathrm{ng} / \mathrm{L}$. Kang et al. ${ }^{159}$ reported the ability of the fungus Cunninghamella elegans (ATCC 9245) to biodegrade gemfibrozil in a liquid culture medium through hydroxylation reactions. Comparative evaluations were conducted by Grenni et al. ${ }^{158}$ with sterile and nonsterile river water incubated in the dark. No biodegradation of gemfibrozil occurred with sterile river water, whereas with micro- biologically active water, a considerable reduction of gemfibrozil was observed, and the FISH analysis conducted on the microbial community revealed a noteworthy increase in the gamma-Proteobacteria group, suggesting that some populations of this group are involved in gemfibrozil degradation.

2.2.7. Antidiabetics. Although it has been estimated that a considerable part of the human population $(3 \%-5 \%)$ suffers from diabetes mellitus type 2 , antidiabetics have not yet received as much attention as the other classes of pharmaceuticals in terms of environmental impact. Taking into consideration the significant number of people suffering from this disease and its chronicity, a large amount of antidiabetics are and will be used and subsequently excreted along with their metabolites, eventually ending up in the WWTP.

Mrozik and Stefańska ${ }^{160}$ assessed the capacity of three natural and representative soils of Central Europe (alluvial agricultural, Loessy Brown, and Podsolic Poland) to sorb and biodegrade glibenclamide, gliclazide, glimepiride, and metformin. The following biodegradation order was observed: metformin $(\mathrm{MET})>$ gliclazide $(\mathrm{GC})>$ glimepiride $(\mathrm{GL})>$ glibenclamide (GB). It was also observed that after 120 days and under aerobic conditions, the type of soil and its physicalchemical properties played an important role in the sorption of MET, GC, GL, and GB. The alluvial agricultural was the most sorbing soil tested. It was also rich in organic matter, had a high cation exchange capacity, and had the highest fraction of fine clays, which increased significantly its sorption capacity.

2.3. Restrictions and Strategies for Inclusion of Biodegradation Processes in WWTP. Igos et al. ${ }^{161}$ made an exhaustive life cycle assessment comparison between two different protocols for pharmaceuticals abatement in WWTP. They considered the conventional treatment chain and the upgraded version with an ozonation step versus the decentralized approach, with a membrane biological reactor followed by specific treatments (ozonation, activated carbon adsorption, or ultraviolet radiation) at specific source points (as the outflow of hospitals). They concluded that life cycle assessment (LCA) is a holistic approach that hardly considers issues that may become highly relevant at the local level, but all the technologies considered for pharmaceuticals pollution abatement have some environmental impact per se, mainly in terms of sludge production. Nevertheless, the decentralized approach with the membrane biological reactor revealed to have a smaller environmental impact than the conventional integrated approach, with little advantage on the use of the post-treatment technologies. This work justifies the consideration of the biologic pathway to remove and/or degrade this class of contaminants, as well as its restrictions.

According to the literature, the major restrictions of biodegradation processes in WWTP are as follows:

- Limited time for microorganisms to adapt to the toxic compounds: According to Dionisi, ${ }^{14}$ microorganisms able to use hazardous compounds as the primary or sole carbon and energy source might have been in contact with these compounds presumably for a long period, having the necessary time to develop mechanisms for adaptation and survival in these hostile conditions. In activated sludge processes, for example, the residence time for microorganisms is frequently several months, but it can be limited just to some days. In these 


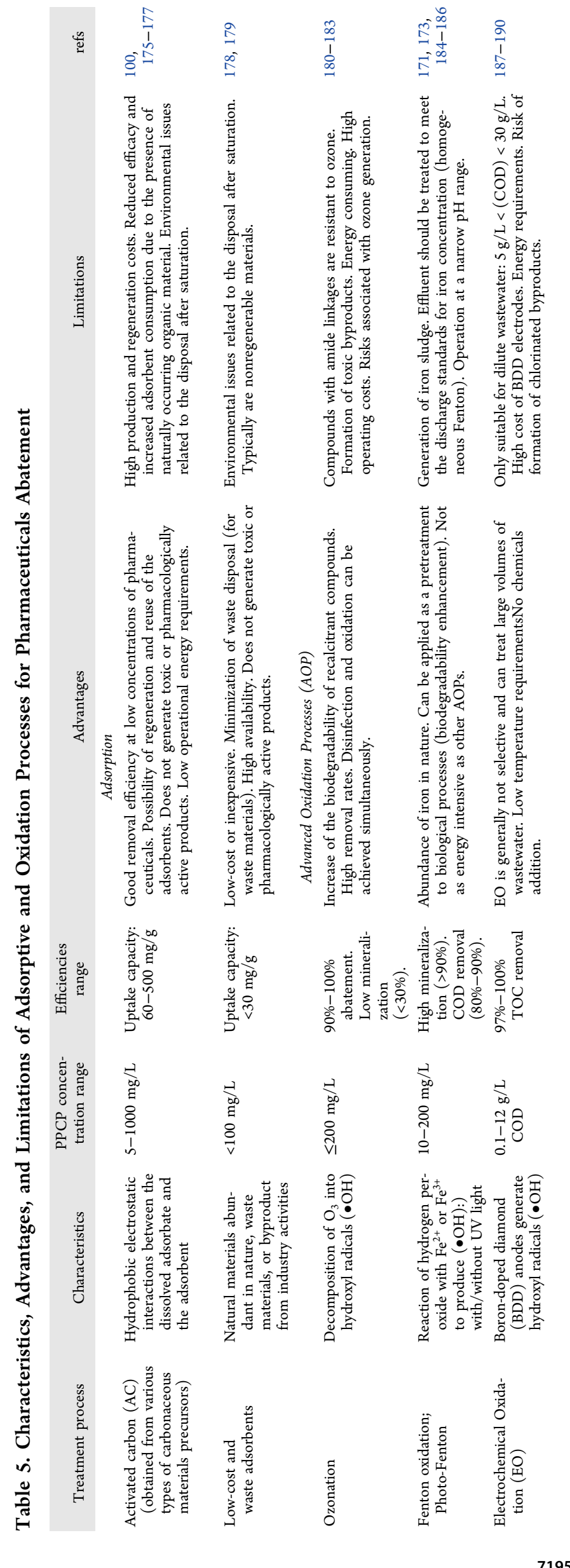


circumstances, microorganisms might not have sufficient contact time to stimulate the competent enzymes to grow on these substrates.

- Limited availability of external carbon sources for cometabolism: For the co-metabolic processes, biodegradation can only occur if external biodegradable substrates are present. Thus, a probable restriction to co-metabolic biodegradation is the availability of other substrates, particularly when the ratio of toxic compounds to other biodegradable substrates in the influent is high and when the SRT is reduced. ${ }^{162}$

- Competition with abiotic removal mechanisms: Biological degradation is possible if the substrate is dissolved in the liquid phase. In biological WWTP, the competing removal mechanisms of adsorption and air stripping decrease the concentration of the toxic compounds in the liquid phase, thus reducing the substrate availability for biodegradation. ${ }^{163}$ The predisposition of a compound to be removed by air stripping depends on the Henry's constant of the substance and on the air flow rate. On the other hand, adsorption on activated sludge flocks depends on the solids retention time and on the partition coefficient of the compound between the liquid and the solid phase, ${ }^{162,163}$ which is often considered proportional to the octanol-water partition coefficient of the chemical. ${ }^{163,164}$ The influence of sludge age on adsorption of any contaminant relates to the fact that only the produced biomass is available for adsorption and that the biomass production rate is intrinsically dependent on the current sludge age. Thus, the older the sludge is, the poorer the removal of a given compound by adsorption is. ${ }^{162}$

- Reduced concentration of toxic compounds in the influent: According to Hoehler, ${ }^{165}$ a minimum bulk substrate concentration is mandatory to create sufficient energy for the phosphorylation of adenosine diphosphate $(\mathrm{ADP})$ to adenosine triphosphate (ATP) and to ensure the maintenance necessities of the microorganisms.

- Intrinsic nonbiodegradability: As mentioned before, there is very little evidence of biodegradation of important hazardous compounds, including pharmaceuticals, polycyclic aromatic hydrocarbons (PAH) with a number of rings higher than 4, flame retardants, and pesticides in biological WWTP. Nevertheless, it is not evident whether this is due to intrinsic thermodynamics or kinetic restrictions or simply to the fact that the microorganisms able to do it have not been identified so far. $^{162}$

The main parameter affecting biodegradation in WWTP is the SRT since for any given substrate the longer the SRT is, the higher the biomass concentration in the system is and the higher the removal rate by biodegradation per unit volume of the biological reactor is. The increase in the SRT should be thoroughly considered since the removal of a hazardous compound by co-metabolism depends on the presence of other more readily biodegradable carbon sources. Generally, beyond a certain value of the SRT, all the readily or slowly biodegradable carbon sources are removed, and consequently, any additional increase in the SRT will not bring any benefits, as there will be no other carbon source available to support cometabolism. An increase in the SRT is also likely to cause a decrease in the removal by adsorption processes. ${ }^{162}$ Air flow rate may also affect the efficiency of biodegradation. Indeed, the higher the airflow rate is, the higher the removal of a given compound by stripping is. Consequently, decreasing the air flow rate can promote a raise in the fraction of the influent substrate that is biodegraded, instead of transferring it to the gas phase. A promising enhancement to the co-metabolic biodegradation of hazardous substances is the external addition of immediately and easily biodegradable substrates, in a similar way to what has been done in nitrification-denitrification processes for nitrogen removal with postdenitrification processes added subsequently. ${ }^{166,167}$ In WWTP, the external readily biodegradable substrate could be added in a specific reactor for hazardous compounds removal, placed, for example, after the main aeration tank. In this specific reactor, all the biodegradable substrates may be completely degraded, and therefore, hazardous compounds removal can only happen due to the addition of the external biodegradable substrate. The combination of anaerobic-aerobic processes is an appealing alternative for the abatement of toxic substances that are hardly biodegradable under exclusively aerobic conditions. Several examples of successful use of anaerobic-aerobic processes for the biodegradation of toxic compounds have been reported in the literature. ${ }^{168-170}$

2.4. Alternative Technologies for Abatement of Pharmaceuticals. A number of technologies have been proposed for the treatment of wastewater containing PPCP mainly dealing with the effluent from tertiary WWTP. Conventional treatment processes include the activated sludge process, trickling filtration, and powdered-carbon-fed activated sludge process. ${ }^{171}$ Highly biodegradable pharmaceuticals can be completed degraded through aerobic biological processes or at least degraded to harmless substances. Nevertheless, conventional processes based on activated sludge are generally not sufficient to ensure total removal for most PPCP. There are several other processes available for the treatment of pharmaceutical wastes such as membrane techniques (ultrafiltration, nanofiltration, reverse osmosis) and adsorptive (powdered activated carbon and granular activated carbon) and oxidative processes (ozonation and advanced oxidation processes). Among these, adsorptive treatments and oxidations processes have been extensively studied and proposed as alternatives or as coupling technologies to biosorption and biodegradation processes. Table 5 presents the main advantages and limitations of adsorptive and oxidation processes, along with the initial concentrations used and efficiencies attained. Hybrid processes, which are a combination of one or more conventional/advanced treatments, may be very effective in the complete eradication of pharmaceutical contaminants. ${ }^{172}$ In order to ensure the economic optimization of the combined process, it is necessary to limit the intensity and/or duration of the advanced treatments due to their high cost. ${ }^{173}$ Appropriate techniques must be combined to provide technically and economically feasible solutions. ${ }^{174}$

\section{PERSPECTIVES AND OUTLOOK}

Sustainable development was defined 30 years ago by the United Nations World Commission on Environment and Development in its report "Our Common Future" as the ability of the present generations to meet their needs, without compromising future generations to meet their own. Technological development and scientific advances allowed humanity to increase life expectancy and quality, supported on 
longer and better education, clever diets, more efficient pharmaceuticals, more suitable housing, and mainly on the consciousness of the impact of pollution, of contamination, and side effects of the new substances uptake in the environment and in living beings that development has brought, along with the advantages of the very same substances. Today, we cannot imagine a world without vaccines, antibiotics, blood pressure and cholesterol regulators, birth control pills, antidepressants, analgesics, sleeping pills, and so many other pharmaceuticals. To be effective, these formulations do need a minimum concentration of the active principles, but they include many other compounds that make them accessible to the individual that needs the medicine. It is known that only a fraction of the pharmaceutical is entrapped by the body, most of it is excreted reaching wastewater that may transport the pharmaceutical molecules toward rivers, oceans, ponds, soils, and sediments. Although reduced amounts of these contaminants are the responsibility of each of us, considering the urban concentrations and the worldwide population, the overall impact of these residues is huge. In fact, many distinct active principles are already detected in those ecosystems, with unforeseen effects on local biota. The common WWTP are not prepared to tackle these emergent pollutants, mainly with secondary treatment based on the activity of consortia of microorganisms. These may suffer the toxicological impact of the emergent molecules affecting their efficiency in COD and BOD abatement. At the best, they may survive the impact, but the pollutant charge will pass through the station without any degradation.

It is also the authors' opinions that the lack of standard protocols and analytical techniques to assess contaminated effluents leads to the involvement of a large number of variables, increasing thus the difficulty in the evaluation and comparison of the processes employed, in terms of efficiency and maximum capacity. The need to perform a pretreatment in the material to be used as decontaminating agents or the need to pretreat industrial effluents, for example, prior to their discharge, significantly increases the amount of wastes produced, which will also require treatment, thus increasing the human impact on the environment. The best way to protect ourselves and the environment is to reduce the use of pharmaceuticals to the minimum possible and when necessary to strictly follow the prescriptions avoiding the risk of microbial resistance and the consumption of additional medicines.

With a circular economy approach, the recovery and reuse of natural resources that otherwise will disappear in the near future should be implemented. The new trend is to rehabilitate contaminated systems with pharmaceutical molecules through the ability of certain microorganisms to entrap and degrade the pollutant molecules. Microbes are ubiquitous and easily collected and maintained, and they behave like microtreatment stations. The complete biodegradation reduces the medicine molecule to carbon dioxide and water, so it is up to the present generation to use bacteria, yeasts, algae, or fungi as exceptional sorbents and degraders to be used in engineered rigs as permeable biobarriers that avoid the contamination of soils and sediments, while rehabilitating polluted water. The present knowledge on microbial genetic modifications may contribute to a highly specialized structure to retain a wide variety of xenobiotic formulations.

\section{ASSOCIATED CONTENT}

\section{Supporting Information}

The Supporting Information is available free of charge on the ACS Publications website at DOI: 10.1021/acs.est.8b06977.

Information on the development and/or improvement of pharmaceutical formulas in the different health areas (Figure S1). It is also presented a schematic summary regarding the application of biological processes to contaminated environmental matrices (Figure S2) and a table (Table S1) with the most popular pharmaceuticals detected in water bodies and their respective concentrations.(PDF)

\section{AUTHOR INFORMATION}

\section{Corresponding Author}

*E-mail: filomenacpcosta@ceb.uminho.pt.

ORCID

Filomena Costa: 0000-0003-3914-6317

Bruna Silva: 0000-0002-6575-7472

\section{Notes}

The authors declare no competing financial interest.

\section{ACKNOWLEDGMENTS}

This study was supported by the Portuguese Foundation for Science and Technology (FCT) under the scope of the research project PTDC/AAG-TEC/5269/2014, the strategic funding of the UID/BIO/04469/2013 unit, and BioTecNorte operation (NORTE-01-0145-FEDER-000004) funded by the European Regional Development Fund under the scope of Norte2020 - Programa Operacional Regional do Norte.

\section{REFERENCES}

(1) Chojnacka, K. Biosorption and Bioaccumulation - the Prospects for Practical Applications. Environ. Int. 2010, 36 (3), 299-307.

(2) Wu, Y.; Li, T.; Yang, L. Mechanisms of Removing Pollutants from Aqueous Solutions by Microorganisms and Their Aggregates: A Review. Bioresour. Technol. 2012, 107, 10.

(3) Fomina, M.; Gadd, G. M. Biosorption: Current Perspectives on Concept, Definition and Application. Bioresour. Technol. 2014, 160, 3-14.

(4) Ayangbenro, A. S.; Babalola, O. O. A New Strategy for Heavy Metal Polluted Environments: A Review of Microbial Biosorbents. Int. J. Environ. Res. Public Health 2017, 14, 94.

(5) Silva, B.; Costa, F.; Neves, I. C.; Tavares, T. Psychiatric Pharmaceuticals as Emerging Contaminants in Wastewater; Springer International Publishing, 2015. DOI: 10.1007/978-3-319-20493-2.

(6) Barra Caracciolo, A.; Topp, E.; Grenni, P. Pharmaceuticals in the Environment: Biodegradation and Effects on Natural Microbial Communities. A Review. J. Pharm. Biomed. Anal. 2015, 106, 25-36.

(7) Veach, A.; Bernot, M. J.; Mitchell, J. K. The Influence of Six Pharmaceuticals on Freshwater Sediment Microbial Growth Incubated at Different Temperatures and UV Exposures. Biodegradation 2012, 23 (4), 497-507.

(8) Sameera, V.; Naga Deepthi, C.; Srinu Babu, G.; Ravi Teja, Y. Role of Biosorption in Environmental Cleanup. J. Microb. Biochem. Technol. 2011, 3 (3), 1-8.

(9) Gadd, G. M. Biosorption: Critical Review of Scientific Rationale, Environmental Importance and Significance for Pollution Treatment. J. Chem. Technol. Biotechnol. 2009, 84 (1), 13-28.

(10) Vijayaraghavan, K.; Yun, Y. S. Bacterial Biosorbents and Biosorption. Biotechnol. Adv. 2008, 26 (3), 266-291.

(11) Costa, F.; Tavares, T. Biosorption of Nickel and Cadmium in the Presence of Diethylketone by a Streptococcus Equisimilis Biofilm 
Supported on Vermiculite. Int. Biodeterior. Biodegrad. 2016, 115, 119132.

(12) Quintelas, C.; Costa, F.; Tavares, T. Bioremoval of Diethylketone by the Synergistic Combination of Microorganisms and Clays: Uptake, Removal and Kinetic Studies. Environ. Sci. Pollut. Res. 2013, 20 (3), 1374-1383.

(13) Costa, F.; Neto, M.; Nicolau, A.; Tavares, T. Biodegradation of Diethylketone by Penicillium Sp. and Alternaria Sp. - A Comparative Study Biodegradation of Diethylketone by Fungi. Curr. Biochem. Eng. 2015, 2, 81-89.

(14) Dionisi, D. Potential and Limits of Biodegradation Processes for the Removal of Organic Xenobiotics from Wastewaters. ChemBioEng Rev. 2014, 1 (2), 67-82.

(15) Costa, F.; Tavares, T. Bioremoval of Ni and Cd in the Presence of Diethylketone by Fungi and by Bacteria - A Comparative Study. Int. Biodeterior. Biodegrad. 2017, 120, 115-123.

(16) Samer, M. Biological and Chemical Wastewater Treatment Processes. Wastewater Treat. Eng. 2015, 1-50.

(17) Ahammad, S. Z.; Sreekrishnan, T. R. Energy from Wastewater Treatment. Bioremediation and Bioeconomy 2016, 523-536.

(18) Costa, F.; Tavares, T. Biosorption of Multicomponent Solutions: A State of the Art of the Understudy Case, 2018. DOI: 10.5772/ intechopen.72179.

(19) Volesky, B. Biosorption of Heavy Metals; CRC press: Boca Raton, FL, 1990.

(20) Michalak, I.; Chojnacka, K.; Witek-Krowiak, A. State of the Art for the Biosorption Process - A Review. Appl. Biochem. Biotechnol. 2013, 170 (6), 1389-1416.

(21) Liu, J.-L.; Wong, M.-H. Pharmaceuticals and Personal Care Products (PPCPs): A Review on Environmental Contamination in China. Environ. Int. 2013, 59, 208-224.

(22) Costa, F.; Tavares, T. Sorption Studies of Diethylketone in the Presence of $\mathrm{Al} 3+, \mathrm{Cd} 2+, \mathrm{Ni} 2+$ and $\mathrm{Mn} 2+$, from Lab-Scale to Pilot Scale. Environ. Technol. 2017, 38 (22), 2811-2823.

(23) Volesky, B. Sorption and Biosorption; BV Sorbex: Montreal, 2003.

(24) Aksu, Z.; Tunç, Ö. Application of Biosorption for Penicillin G Removal: Comparison with Activated Carbon. Process Biochem. 2005, 40 (2), 831-847.

(25) Volesky, B.; Holan, Z. R. Biosorption of Heavy Metals. Biotechnol. Prog. 1995, 11 (3), 235-250.

(26) Volesky, B. Biosorption and Me. Water Res. 2007, 41 (18), 4017-4029.

(27) Malik, A. Metal Bioremediation through Growing Cells. Environ. Int. 2004, 30 (2), 261-278.

(28) Barros, Ó.; Costa, L.; Costa, F.; Lago, A.; Rocha, V.; Vipotnik, Z.; Silva, B.; Tavares, T. Recovery of Rare Earth Elements from Wastewater Towards a Circular Economy. Molecules 2019, 24 (6), 1005.

(29) Seniunaitè, J.; Vaiškunaitè, R.; Bolutienè, V. Coffee Grounds as an Adsorbent for Copper and Lead Removal Form Aqueous Solutions. The 9th International Conference "Environmental Engineering 2014 2014, No. May, 1-6.

(30) Karamushka, V. I.; Gadd, G. M. Interaction of Saccharomyces Cerevisiae with Gold: Toxicity and Accumulation. BioMetals 1999, 12 (4), 289-294.

(31) Aksu, Z. Application of Biosorption for the Removal of Organic Pollutants: A Review. Process Biochem. 2005, 40 (3-4), 997-1026.

(32) Tran, V. S.; Ngo, H. H.; Guo, W.; Zhang, J.; Liang, S.; TonThat, C.; Zhang, X. Typical Low Cost Biosorbents for Adsorptive Removal of Specific Organic Pollutants from Water. Bioresour. Technol. 2015, 182, 353-363.

(33) Flores-Chaparro, C. E.; Chazaro Ruiz, L. F.; Alfaro de la Torre, M. C.; Huerta-Diaz, M. A.; Rangel-Mendez, J. R. Biosorption Removal of Benzene and Toluene by Three Dried Macroalgae at Different Ionic Strength and Temperatures: Algae Biochemical Composition and Kinetics. J. Environ. Manage. 2017, 193, 126-135.
(34) Kodal, S. P.; Aksu, Z. Cationic Surfactant-Modified Biosorption of Anionic Dyes by Dried Rhizopus Arrhizus. Environ. Technol. 2017, 38 (20), 2551-2561.

(35) Ara, B.; Shah, J.; Jan, M. R.; Aslam, S. Removal of Metribuzin Herbicide from Aqueous Solution Using Corn Cob. Int. J. Sci. Environ. 2013, 2 (2), 146-161.

(36) Al-Zaben, M. I.; Mekhamer, W. K. Removal of 4-Chloro-2Methyl Phenoxy Acetic Acid Pesticide Using Coffee Wastes from Aqueous Solution. Arab. J. Chem. 2017, 10, S1523.

(37) Hubbe, M. A.; Park, J.; Park, S. Cellulosic Substrates for Removal of Pollutants from Aqueous Systems: A Review. Part 4. Dissolved Petrochemical Compounds. Bio Resources 2014, 9 (4), $7782-7925$.

(38) Holm, J. V.; Rugge, K.; Bjerg, P. L.; Christensen, T. H. Pharmaceutical Organic Compounds in the Groundwater Downgradient of a Landtill. Environ. Sci. Technol. 1995, 29 (5), 1415-1420.

(39) Ternes, T. A. Occurrence of Drugs in German Sewage Treatment Plants and Rivers. Water Res. 1998, 32 (11), 3245-3260.

(40) Daughton, C.; Ternes, T. Pharmaceuticals and Personal Care Products in the Enviornment: Agents of Subtle Change? Environ. Health Perspect. 1999, 107 (Suppl 6), 907-938.

(41) Cherifi, H.; Bentahar, F.; Salah, H. Biosorption of Pharmaceutical Pollutant. In Progress in Clean Energy 1; Springer International Publishing, 2015; pp 739-750. DOI: 10.1007/978-3319-16709-1_54.

(42) Wang, J.; Wang, S. Removal of Pharmaceuticals and Personal Care Products (PPCPs) from Wastewater: A Review. J. Environ. Manage. 2016, 182, 620-640.

(43) Tiwari, B.; Sellamuthu, B.; Ouarda, Y.; Drogui, P.; Tyagi, R. D.; Buelna, G. Review on Fate and Mechanism of Removal of Pharmaceutical Pollutants from Wastewater Using Biological Approach. Bioresour. Technol. 2017, 224, 1-12.

(44) Heberer, T.; Schmidt-Baumler, K.; Stan, H. J. Occurrence and Distribution of Organic Contaminants in the Aquatic System in Berlin. Part 1: Drug Residues and Other Polar Contaminants in Berlin Surface and Groundwater. Acta Hydrochim. Hydrobiol. 1998, 26, 272278.

(45) Andreozzi, R.; Canterino, M.; Marotta, R.; Paxeus, N. Antibiotic Removal from Wastewaters: The Ozonation of Amoxicillin. J. Hazard. Mater. 2005, 122 (3), 243-250.

(46) He, Y.; Langenhoff, A. A. M.; Comans, R. N. J.; Sutton, N. B.; Rijnaarts, H. H. M. Effects of Dissolved Organic Matter and Nitrification on Biodegradation of Pharmaceuticals in Aerobic Enrichment Cultures. Sci. Total Environ. 2018, 630, 1335-1342.

(47) Worch, E. Adsorption Technology in Water Treatment: Fundamentals, Processes, and Modeling; Walter de Gruyter: Berlin, Boston, 2012.

(48) Suárez, S.; Carballa, M.; Omil, F.; Lema, J. M. How Are Pharmaceutical and Personal Care Products (PPCPs) Removed from Urban Wastewaters? Rev. Environ. Sci. Bio/Technol. 2008, 7 (2), 125138.

(49) Kyzas, G. Z.; Fu, J.; Lazaridis, N. K.; Bikiaris, D. N.; Matis, K. A. New Approaches on the Removal of Pharmaceuticals from Wastewaters with Adsorbent Materials. J. Mol. Liq. 2015, 209, 87-93.

(50) Zhang, S.; Gitungo, S.; Axe, L.; Dyksen, J. E.; Raczko, R. F. A Pilot Plant Study Using Conventional and Advanced Water Treatment Processes: Evaluating Removal Efficiency of Indicator Compounds Representative of Pharmaceuticals and Personal Care Products. Water Res. 2016, 105, 85-96.

(51) Murray, A.; Örmeci, B.; Lai, E. P. C. Use of Sub-Micron Sized Resin Particles for Removal of Endocrine Disrupting Compounds and Pharmaceuticals from Water and Wastewater. J. Environ. Sci. 2017, 51, $256-264$.

(52) Mirzaei, A.; Chen, Z.; Haghighat, F.; Yerushalmi, L. Removal of Pharmaceuticals and Endocrine Disrupting Compounds from Water by Zinc Oxide-Based Photocatalytic Degradation: A Review. Sustain. Cities Soc. 2016, 27, 407-418. 
(53) Sui, Q.; Cao, X.; Lu, S.; Zhao, W.; Qiu, Z.; Yu, G. Occurrence, Sources and Fate of Pharmaceuticals and Personal Care Products in the Groundwater: A Review. Emerg. Contam. 2015, 1 (1), 14-24.

(54) Kümmerer, K. Antibiotics in the Aquatic Environment - A Review - Part II. Chemosphere 2009, 75 (4), 435-441.

(55) Pereira, A. M. P. T.; Silva, L. J. G.; Meisel, L. M.; Lino, C. M.; Pena, A. Environmental Impact of Pharmaceuticals from Portuguese Wastewaters: Geographical and Seasonal Occurrence, Removal and Risk Assessment. Environ. Res. 2015, 136, 108-119.

(56) Petrovic, M.; de Alda, M. J. L.; Diaz-Cruz, S.; Postigo, C.; Radjenovic, J.; Gros, M.; Barcelo, D. Fate and Removal of Pharmaceuticals and Illicit Drugs in Conventional and Membrane Bioreactor Wastewater Treatment Plants and by Riverbank Filtration. Philos. Trans. R. Soc., A 2009, 367 (1904), 3979.

(57) Barnes, K. K.; Kolpin, D. W.; Furlong, E. T.; Zaugg, S. D.; Meyer, M. T.; Barber, L. B. A National Reconnaissance of Pharmaceuticals and Other Organic Wastewater Contaminants in the United States - I) Groundwater. Sci. Total Environ. 2008, 402 (2-3), 192-200.

(58) He, Y.; Sutton, N. B.; Rijnaarts, H. H. M.; Langenhoff, A. A. M. Pharmaceutical Biodegradation under Three Anaerobic Redox Conditions Evaluated by Chemical and Toxicological Analyses. Sci. Total Environ. 2018, 618, 658-664.

(59) Gaw, S.; Thomas, K. V.; Hutchinson, T. H. Sources, Impacts and Trends of Pharmaceuticals in the Marine and Coastal Environment. Philos. Trans. R. Soc. B Biol. Sci. 2014, 369 (1656), 20130572.

(60) Gross-Sorokin, M. Y.; Roast, S. D.; Brighty, G. C. Assessment of Feminization of Male Fish in English Rivers by the Environment Agency of England and Wales. Environ. Health Perspect. 2006, 114 (Suppl 1), 147-151.

(61) Niemuth, N. J.; Klaper, R. D. Emerging Wastewater Contaminant Metformin Causes Intersex and Reduced Fecundity in Fish. Chemosphere 2015, 135, 38-45.

(62) Margiotta-Casaluci, L.; Hannah, R. E.; Sumpter, J. P. Mode of Action of Human Pharmaceuticals in Fish: The Effects of the 5-AlphaReductase Inhibitor, Dutasteride, on Reproduction as a Case Study. Aquat. Toxicol. 2013, 128-129, 113-123.

(63) Gagné, F.; Blaise, C.; André, C. Occurrence of Pharmaceutical Products in a Municipal Effluent and Toxicity to Rainbow Trout (Oncorhynchus Mykiss) Hepatocytes. Ecotoxicol. Environ. Saf. 2006, 64 (3), 329-336.

(64) Farré, M. la; Pérez, S.; Kantiani, L.; Barceló, D. Fate and Toxicity of Emerging Pollutants, Their Metabolites and Transformation Products in the Aquatic Environment. TrAC, Trends Anal. Chem. 2008, 27 (11), 991-1007.

(65) Fent, K.; Weston, A. A.; Caminada, D. Ecotoxicology of Human Pharmaceuticals. Aquat. Toxicol. 2006, 76 (2), 122-159.

(66) Ratola, N.; Cincinelli, A.; Alves, A.; Katsoyiannis, A. Occurrence of Organic Microcontaminants in the Wastewater Treatment Process. A Mini Review. J. Hazard. Mater. 2012, 239$240,1-18$.

(67) Jones, O. A. H.; Voulvoulis, N.; Lester, J. N. Human Pharmaceuticals in the Aquatic Environment a Review. Environ. Technol. 2001, 22 (12), 1383-1394.

(68) Santos, L. H. M. L. M.; Araújo, A. N.; Fachini, A.; Pena, A.; Delerue-Matos, C.; Montenegro, M. C. B. S. M. Ecotoxicological Aspects Related to the Presence of Pharmaceuticals in the Aquatic Environment. J. Hazard. Mater. 2010, 175 (1-3), 45-95.

(69) Rahman, M. F.; Yanful, E. K.; Jasim, S. Y. Endocrine Disrupting Compounds (EDCs) and Pharmaceuticals and Personal Care Products (PPCPs) in the Aquatic Environment: Implications for the Drinking Water Industry and Global Environmental Health. J. Water Health 2009, 7 (2), 224-243.

(70) Fan, H.; Li, J.; Zhang, L.; Feng, L. Contribution of Sludge Adsorption and Biodegradation to the Removal of Five Pharmaceuticals in a Submerged Membrane Bioreactor. Biochem. Eng. J. 2014, 88, 101-107.
(71) Antunes, M.; Esteves, V. I.; Guégan, R.; Crespo, J. S.; Fernandes, A. N.; Giovanela, M. Removal of Diclofenac Sodium from Aqueous Solution by Isabel Grape Bagasse. Chem. Eng. J. 2012, 192, 114-121.

(72) Haroune, L.; Saibi, S.; Bellenger, J.-P.; Cabana, H. Evaluation of the Efficiency of Trametes Hirsuta for the Removal of Multiple Pharmaceutical Compounds under Low Concentrations Relevant to the Environment. Bioresour. Technol. 2014, 171, 199-202.

(73) Zhou, A.; Zhang, Y.; Li, R.; Su, X.; Zhang, L. Adsorptive Removal of Sulfa Antibiotics from Water Using Spent Mushroom Substrate, an Agricultural Waste. Desalin. Water Treat. 2016, 57 (1), 388-397.

(74) Navarro, A. E.; Lim, H.; Chang, E.; Lee, Y.; Manrique, A. S. Uptake of Sulfa Drugs from Aqueous Solutions by Marine Algae. Sep. Sci. Technol. 2014, 49 (14), 2175-2181.

(75) Mihciokur, H.; Oguz, M. Removal of Oxytetracycline and Determining Its Biosorption Properties on Aerobic Granular Sludge. Environ. Toxicol. Pharmacol. 2016, 46, 174-182.

(76) Liu, Z.; Zhou, X.; Chen, X.; Dai, C.; Zhang, J.; Zhang, Y. Biosorption of Clofibric Acid and Carbamazepine in Aqueous Solution by Agricultural Waste Rice Straw. J. Environ. Sci. 2013, 25 (12), 2384-2395.

(77) Álvarez-Torrellas, S.; Muñoz, M.; Zazo, J. A.; Casas, J. A.; García, J. Synthesis of High Surface Area Carbon Adsorbents Prepared from Pine Sawdust-Onopordum Acanthium L. for Nonsteroidal Anti-Inflammatory Drugs Adsorption. J. Environ. Manage. 2016, 183, 294-305.

(78) Davies, N. M.; Andersen, K. E. Clinical Pharmacokinetics of Diclofenac. Therapeutic Insights and Pitfalls. Clin. Pharmacokinet. 1997, 33 (3), 184-213.

(79) Bernardo, M.; Rodrigues, S.; Lapa, N.; Matos, I.; Lemos, F.; Batista, M. K. S.; Carvalho, A. P.; Fonseca, I. High Efficacy on Diclofenac Removal by Activated Carbon Produced from Potato Peel Waste. Int. J. Environ. Sci. Technol. 2016, 13 (8), 1989-2000.

(80) Joss, A.; Zabczynski, S.; Göbel, A.; Hoffmann, B.; Löffler, D.; McArdell, C. S.; Ternes, T. A.; Thomsen, A.; Siegrist, H. Biological Degradation of Pharmaceuticals in Municipal Wastewater Treatment: Proposing a Classification Scheme. Water Res. 2006, 40 (8), 16861696.

(81) Schwaiger, J.; Ferling, H.; Mallow, U.; Wintermayr, H.; Negele, R. D. Toxic Effects of the Non-Steroidal Anti-Inflammatory Drug Diclofenac: Part I: Histopathological Alterations and Bioaccumulation in Rainbow Trout. Aquat. Toxicol. 2004, 68 (2), 141-150.

(82) World Health Organization. http://www.who.int/ (accessed August 10, 2018).

(83) Wang, C.; Yu, Y.; Yin, L.; Niu, J.; Hou, L.-A. Insights of Ibuprofen Electro-Oxidation on Metal-Oxide-Coated Ti Anodes: Kinetics, Energy Consumption and Reaction Mechanisms. Chemosphere 2016, 163, 584-591.

(84) Mondal, S.; Aikat, K.; Halder, G. Biosorptive Uptake of Ibuprofen by Chemically Modified Parthenium Hysterophorus Derived Biochar: Equilibrium, Kinetics, Thermodynamics and Modeling. Ecol. Eng. 2016, 92, 158-172.

(85) Martin, D. F.; Martin, J. M.; Ward, T. A. Removal of Selected NSAIDs (Nonsteroidal Anti-Inflammatory Drugs) in Aqueous Samples by Octolig®. J. Environ. Sci. Health, Part A: Toxic/Hazard. Subst. Environ. Eng. 2016, 51 (2), 186-191.

(86) Rosal, R.; Rodríguez, A.; Perdigón-Melón, J. A.; Petre, A.; García-Calvo, E.; Gómez, M. J.; Agüera, A.; Fernández-Alba, A. R. Occurrence of Emerging Pollutants in Urban Wastewater and Their Removal through Biological Treatment Followed by Ozonation. Water Res. 2010, 44 (2), 578-588.

(87) Kim, J.-W.; Jang, H.-S.; Kim, J.-G.; Ishibashi, H.; Hirano, M.; Nasu, K.; Ichikawa, N.; Takao, Y.; Shinohara, R.; Arizono, K. Occurrence of Pharmaceutical and Personal Care Products (PPCPs) in Surface Water from Mankyung River, South Korea. J. Health Sci. 2009, 55 (2), 249-258.

(88) Lishman, L.; Smyth, S. A.; Sarafin, K.; Kleywegt, S.; Toito, J.; Peart, T.; Lee, B.; Servos, M.; Beland, M.; Seto, P. Occurrence and 
Reductions of Pharmaceuticals and Personal Care Products and Estrogens by Municipal Wastewater Treatment Plants in Ontario, Canada. Sci. Total Environ. 2006, 367 (2-3), 544-558.

(89) Adrian, J.; Fernández, F.; Muriano, A.; Obregón, R.; Ramón, J.; Tort, N.; Marco, M. P. Immunochemical Analytical Methods for Monitoring the Aquatic Environment. In Analytical Measurements in Aquatic Environments; Namiesnik, J., Szefer, P., Eds.; CRC Press, 2009; pp 139-188.

(90) Khalaf, S.; Al-Rimawi, F.; Khamis, M.; Nir, S.; Bufo, S. A.; Scrano, L.; Mecca, G.; Karaman, R. Efficiency of Membrane Technology, Activated Charcoal, and a Micelle-Clay Complex for Removal of the Acidic Pharmaceutical Mefenamic Acid. J. Environ. Sci. Health, Part A: Toxic/Hazard. Subst. Environ. Eng. 2013, 48 (13), $1655-1662$.

(91) Soulet, B.; Tauxe, A.; Tarradellas, J. Analysis of Acidic Drugs in Swiss Wastewaters. Int. J. Environ. Anal. Chem. 2002, 82 (10), 659667.

(92) Colombo, R.; Ferreira, T. C. R.; Ferreira, R. A.; Lanza, M. R. V. Removal of Mefenamic Acid from Aqueous Solutions by Oxidative Process: Optimization through Experimental Design and HPLC/UV Analysis. J. Environ. Manage. 2016, 167, 206-213.

(93) Gros, M.; Petrović, M.; Barceló, D. Wastewater Treatment Plants as a Pathway for Aquatic Contamination by Pharmaceuticals in the Ebro River Basin (Northeast Spain). Environ. Toxicol. Chem. 2007, 26 (8), 1553-1562.

(94) Araujo, L.; Villa, N.; Camargo, N.; Bustos, M.; García, T.; Prieto, A. de J. Persistence of Gemfibrozil, Naproxen and Mefenamic Acid in Natural Waters. Environ. Chem. Lett. 2011, 9 (1), 13-18.

(95) Tauxe-Wuersch, A.; De Alencastro, L. F.; Grandjean, D.; Tarradellas, J. Occurrence of Several Acidic Drugs in Sewage Treatment Plants in Switzerland and Risk Assessment. Water Res. 2005, 39 (9), 1761-1772.

(96) Jones, O. A. H.; Voulvoulis, N.; Lester, J. N. Partitioning Behavior of Five Pharmaceutical Compounds to Activated Sludge and River Sediment. Arch. Environ. Contam. Toxicol. 2006, 50 (3), 297305.

(97) Ahmed, M. J. Adsorption of Non-Steroidal Anti-Inflammatory Drugs from Aqueous Solution Using Activated Carbons: Review. J. Environ. Manage. 2017, 190, 274-282.

(98) Ziylan, A.; Ince, N. H. The Occurrence and Fate of AntiInflammatory and Analgesic Pharmaceuticals in Sewage and Fresh Water: Treatability by Conventional and Non-Conventional Processes. J. Hazard. Mater. 2011, 187 (1-3), 24-36.

(99) Isidori, M.; Lavorgna, M.; Nardelli, A.; Parrella, A.; Previtera, L.; Rubino, M. Ecotoxicity of Naproxen and Its Phototransformation Products. Sci. Total Environ. 2005, 348 (1-3), 93-101.

(100) Ahmed, M. B.; Zhou, J. L.; Ngo, H. H.; Guo, W. Adsorptive Removal of Antibiotics from Water and Wastewater: Progress and Challenges. Sci. Total Environ. 2015, 532, 112-126.

(101) Gothwal, R.; Shashidhar, T. Antibiotic Pollution in the Environment: A Review. Clean: Soil, Air, Water 2015, 43 (4), 479489.

(102) Miao, X.-S.; Bishay, F.; Chen, M.; Metcalfe, C. D. Occurrence of Antimicrobials in the Final Effluents of Wastewater Treatment Plants in Canada. Environ. Sci. Technol. 2004, 38 (13), 3533-3541.

(103) Managaki, S.; Murata, A.; Takada, H.; Tuyen, B. C.; Chiem, N. H. Distribution of Macrolides, Sulfonamides, and Trimethoprim in Tropical Waters: Ubiquitous Occurrence of Veterinary Antibiotics in the Mekong Delta. Environ. Sci. Technol. 2007, 41 (23), 8004-8010.

(104) Fourest, E.; Volesky, B. Contribution of Sulfonate Groups and Alginate to Heavy Metal Biosorption by the Dry Biomass of Sargassum Fluitans. Environ. Sci. Technol. 1996, 30 (1), 277-282.

(105) Khetan, S. K.; Collins, T. J. Human Pharmaceuticals in the Aquatic Environment: A Challenge to Green Chemistry. Chem. Rev. 2007, 107 (6), 2319-2364.

(106) Mohapatra, D. P.; Brar, S. K.; Tyagi, R. D.; Picard, P.; Surampalli, R. Y. Analysis and Advanced Oxidation Treatment of a Persistent Pharmaceutical Compound in Wastewater and Wastewater Sludge-Carbamazepine. Sci. Total Environ. 2014, 470-471, 58-75.
(107) Mohapatra, D. P.; Brar, S. K.; Tyagi, R. D.; Picard, P.; Surampalli, R. Y. Carbamazepine in Municipal Wastewater and Wastewater Sludge: Ultrafast Quantification by Laser Diode Thermal Desorption-Atmospheric Pressure Chemical Ionization Coupled with Tandem Mass Spectrometry. Talanta 2012, 99, 247-255.

(108) Gao, P.; Ding, Y.; Li, H.; Xagoraraki, I. Occurrence of Pharmaceuticals in a Municipal Wastewater Treatment Plant: Mass Balance and Removal Processes. Chemosphere 2012, 88 (1), 17-24.

(109) Clara, M.; Strenn, B.; Kreuzinger, N. Carbamazepine as a Possible Anthropogenic Marker in the Aquatic Environment: Investigations on the Behaviour of Carbamazepine in Wastewater Treatment and during Groundwater Infiltration. Water Res. 2004, 38 (4), 947-954.

(110) Samara, M.; Nasser, A.; Mingelgrin, U. Mechanochemical Removal of Carbamazepine. Chemosphere 2016, 160, 266-272.

(111) Tixier, C.; Singer, H. P.; Oellers, S.; Müller, S. R. Occurrence and Fate of Carbamazepine, Clofibric Acid, Diclofenac, Ibuprofen, Ketoprofen, and Naproxen in Surface Waters. Environ. Sci. Technol. 2003, 37 (6), 1061-1068.

(112) Yang, B.; Kookana, R. S.; Williams, M.; Du, J.; Doan, H.; Kumar, A. Removal of Carbamazepine in Aqueous Solutions through Solar Photolysis of Free Available Chlorine. Water Res. 2016, 100, 413-420.

(113) Avisar, D.; Horovitz, I.; Lozzi, L.; Ruggieri, F.; Baker, M.; Abel, M.-L.; Mamane, H. Impact of Water Quality on Removal of Carbamazepine in Natural Waters by N-Doped $\mathrm{TiO} 2$ Photo-Catalytic Thin Film Surfaces. J. Hazard. Mater. 2013, 244-245, 463-471.

(114) Li, X.; Xu, J.; de Toledo, R. A.; Shim, H. Enhanced Carbamazepine Removal by Immobilized Phanerochaete Chrysosporium in a Novel Rotating Suspension Cartridge Reactor under NonSterile Condition. Int. Biodeterior. Biodegrad. 2016, 115, 102-109.

(115) Vasiliadou, I. A.; Molina, R.; Martínez, F.; Melero, J. A. Experimental and Modeling Study on Removal of Pharmaceutically Active Compounds in Rotating Biological Contactors. J. Hazard. Mater. 2014, 274, 473-482.

(116) Monteiro, S. C.; Boxall, A. B. A. Occurrence and Fate of Human Pharmaceuticals in the Environment. In Reviews of Environmental Contamination and Toxicology; Springer: New York, 2010; pp 53-154. DOI: 10.1007/978-1-4419-1157-5 2.

(117) Paje, M. L. F.; Kuhlicke, U.; Winkler, M.; Neu, T. R. Inhibition of Lotic Biofilms by Diclofenac. Appl. Microbiol. Biotechnol. 2002, 59 (4-5), 488-492.

(118) Martinez-Hernandez, V.; Meffe, R.; Herrera Lopez, S.; de Bustamante, I. The Role of Sorption and Biodegradation in the Removal of Acetaminophen, Carbamazepine, Caffeine, Naproxen and Sulfamethoxazole during Soil Contact: A Kinetics Study. Sci. Total Environ. 2016, 559, 232-241.

(119) Baena-Nogueras, R. M.; Gonzalez-Mazo, E.; Lara-Martin, P. A. Degradation Kinetics of Pharmaceuticals and Personal Care Products in Surface Waters: Photolysis vs Biodegradation. Sci. Total Environ. 2017, 590-591, 643-654.

(120) Wang, S.; Hu, Y.; Wang, J. Biodegradation of Typical Pharmaceutical Compounds by a Novel Strain Acinetobacter Sp. J. Environ. Manage. 2018, 217, 240-246.

(121) Green, R. E.; Newton, I. A. N.; Shultz, S.; Cunningham, A. A.; Gilbert, M.; Pain, D. J.; Prakash, V. Diclofenac Poisoning as a Cause of Vulture Population Declines across the Indian Subcontinent. J. Appl. Ecol. 2004, 41 (5), 793-800.

(122) Kummerova, M.; Zezulka, S.; Babula, P.; Triska, J. Possible Ecological Risk of Two Pharmaceuticals Diclofenac and Paracetamol Demonstrated on a Model Plant Lemna Minor. J. Hazard. Mater. 2016, 302, 351-361.

(123) Guiloski, I. C.; Ribas, J. L. C.; Pereira, L. da S.; Neves, A. P. P.; Silva de Assis, H. C. Effects of Trophic Exposure to Dexamethasone and Diclofenac in Freshwater Fish. Ecotoxicol. Environ. Saf. 2015, 114, 204-211.

(124) Moreira, I. S.; Bessa, V. S.; Murgolo, S.; Piccirillo, C.; Mascolo, G.; Castro, P. M. L. Biodegradation of Diclofenac by the 
Bacterial Strain Labrys Portucalensis F11. Ecotoxicol. Environ. Saf. 2018, 152, 104-113.

(125) Cruz-Morató, C.; Ferrando-Climent, L.; Rodriguez-Mozaz, S.; Barcelo, D.; Marco-Urrea, E.; Vicent, T.; Sarra, M. Degradation of Pharmaceuticals in Non-Sterile Urban Wastewater by Trametes Versicolor in a Fluidized Bed Bioreactor. Water Res. 2013, 47 (14), 5200-5210.

(126) Chen, Y.; Rosazza, J. P. N. Microbial Transformation of Ibuprofen by a Nocardia Species. Appl. Environ. Microbiol. 1994, 60 (4), 1292-1296.

(127) Lin, A. Y.-C.; Plumlee, M. H.; Reinhard, M. Natural Attenuation of Pharmaceuticals and Alkylphenol Polyethoxylate Metabolites during River Transport: Photochemical and Biological Transformation. Environ. Toxicol. Chem. 2006, 25 (6), 1458-1464.

(128) Marco-Urrea, E.; Pérez-Trujillo, M.; Vicent, T.; Caminal, G. Ability of White-Rot Fungi to Remove Selected Pharmaceuticals and Identification of Degradation Products of Ibuprofen by Trametes Versicolor. Chemosphere 2009, 74 (6), 765-772.

(129) Sanyal, A. K.; Roy, D.; Chowdhury, B.; Banerjee, A. B. Ibuprofen, a Unique Anti-Inflammatory Compound with Antifungal Activity against Dermatophytes. Lett. Appl. Microbiol. 1993, 17 (3), 109-111.

(130) Elvers, K. T.; Wright, S. J. Antibacterial Activity of the AntiInflammatory Compound Ibuprofen. Lett. Appl. Microbiol. 1995, 20 (2), 82-84.

(131) Lawrence, J. R.; Swerhone, G. D. W.; Wassenaar, L. I.; Neu, T. R. Effects of Selected Pharmaceuticals on Riverine Biofilm Communities. Can. J. Microbiol. 2005, 51 (8), 655-669.

(132) Quintana, J. B.; Weiss, S.; Reemtsma, T. Pathways and Metabolites of Microbial Degradation of Selected Acidic Pharmaceutical and Their Occurrence in Municipal Wastewater Treated by a Membrane Bioreactor. Water Res. 2005, 39 (12), 2654-2664.

(133) Wojcieszynska, D.; Domaradzka, D.; Hupert-Kocurek, K.; Guzik, U. Bacterial Degradation of Naproxen-Undisclosed Pollutant in the Environment. J. Environ. Manage. 2014, 145, 157-161.

(134) Rodarte-Morales, A. I.; Feijoo, G.; Moreira, M. T.; Lema, J. M. Biotransformation of Three Pharmaceutical Active Compounds by the Fungus Phanerochaete Chrysosporium in a Fed Batch Stirred Reactor under Air and Oxygen Supply. Biodegradation 2012, 23 (1), 145-156.

(135) De Gusseme, B.; Vanhaecke, L.; Verstraete, W.; Boon, N. Degradation of Acetaminophen by Delftia Tsuruhatensis and Pseudomonas Aeruginosa in a Membrane Bioreactor. Water Res. 2011, 45 (4), 1829-1837.

(136) Zhang, L.; Hu, J.; Zhu, R.; Zhou, Q.; Chen, J. Degradation of Paracetamol by Pure Bacterial Cultures and Their Microbial Consortium. Appl. Microbiol. Biotechnol. 2013, 97 (8), 3687-3698.

(137) Takenaka, S.; Okugawa, S.; Kadowaki, M.; Murakami, S.; Aoki, K. The Metabolic Pathway of 4-Aminophenol in Burkholderia Sp. Strain AK-5 Differs from that of Aniline and Aniline with C-4 Substituents. Appl. Environ. Microbiol. 2003, 69 (9), 5410-5413.

(138) Wei, F.; Zhou, Q.-W.; Leng, S.-Q.; Zhang, L.-L.; Chen, J.-M. Isolation, Identification and Biodegradation Characteristics of a New Bacterial Strain Degrading Paracetamol. Huanjing Kexue/Environmental Sci. 2011, 32, 1812-1819.

(139) Hart, A.; Orr, D. L. J. The Degradation of Paracetamol (4Hydroxyacetanilide) and Other Substituted Acetanilides by a Penicillium Species. Antonie van Leeuwenhoek 1975, 41 (1), 239-247.

(140) Afzal Khan, S.; Hamayun, M.; Ahmed, S. Degradation of 4Aminophenol by Newly Isolated Pseudomonas Sp. Strain ST-4. Enzyme Microb. Technol. 2006, 38 (1-2), 10-13.

(141) Takenaka, S.; Murakami, S.; Shinke, R.; Hatakeyama, K.; Yukawa, H.; Aoki, K. Novel Genes Encoding 2-Aminophenol 1,6Dioxygenase from Pseudomonas Species AP-3 Growing on 2Aminophenol and Catalytic Properties of the Purified Enzyme. J. Biol. Chem. 1997, 272 (23), 14727-14732.

(142) Alvarino, T.; Katsou, E.; Malamis, S.; Suarez, S.; Omil, F.; Fatone, F. Inhibition of Biomass Activity in the via Nitrite Nitrogen
Removal Processes by Veterinary Pharmaceuticals. Bioresour. Technol. 2014, 152, 477-483.

(143) Li, J.; Ye, Q.; Gan, J. Degradation and Transformation Products of Acetaminophen in Soil. Water Res. 2014, 49, 44-52.

(144) Pan, L.-J.; Li, J.; Li, C.-X.; Tang, X.-D.; Yu, G.-W.; Wang, Y. Study of Ciprofloxacin Biodegradation by a Thermus Sp. Isolated from Pharmaceutical Sludge. J. Hazard. Mater. 2018, 343, 59-67.

(145) Nasir, N.; Talib, S. A.; Hashim, S. N.; Tay, C. C. Biodegradation of Carbamazepine Using Fungi and Bacteria. J. Fundam. Appl. Sci. 2018, 9, 124-146.

(146) Bessa, V. S.; Moreira, I. S.; Tiritan, M. E.; Castro, P. M. L. Enrichment of Bacterial Strains for the Biodegradation of Diclofenac and Carbamazepine from Activated Sludge. Int. Biodeterior. Biodegrad. 2017, 120, 135-142.

(147) Wu, S.; Zhang, L.; Chen, J. Paracetamol in the Environment and Its Degradation by Microorganisms. Appl. Microbiol. Biotechnol. 2012, 96 (4), 875-884.

(148) Xiong, J.-Q.; Kurade, M. B.; Abou-Shanab, R. A. I.; Ji, M.-K.; Choi, J.; Kim, J. O.; Jeon, B.-H. Biodegradation of Carbamazepine Using Freshwater Microalgae Chlamydomonas Mexicana and Scenedesmus Obliquus and the Determination of Its Metabolic Fate. Bioresour. Technol. 2016, 205, 183-190.

(149) Pratt, L. A.; Brody, D. J.; Q G. Antidepressant Use in Persons Aged 12 and over: United States, 2005-2008. NCHS Data Brief 2011, October, 1-8.

(150) Kwon, J.-W.; Armbrust, K. L. Laboratory Persistence and Fate of Fluoxetine in Aquatic Environments. Environ. Toxicol. Chem. 2006, 25 (10), 2561-2568.

(151) Moreira, I. S.; Ribeiro, A. R.; Afonso, C. M.; Tiritan, M. E.; Castro, P. M. L. Enantioselective Biodegradation of Fluoxetine by the Bacterial Strain Labrys Portucalensis F11. Chemosphere 2014, 111, $103-111$.

(152) Velázquez, Y. F.; Nacheva, P. M. Biodegradability of Fluoxetine, Mefenamic Acid, and Metoprolol Using Different Microbial Consortiums. Environ. Sci. Pollut. Res. 2017, 24 (7), 6779-6793.

(153) American Heart Association; American Stroke Association Heart Disease and Stroke Statistics 2018 At-a-Glance, 2018.

(154) Buser, H. R.; Poiger, T.; Müller, M. D. Occurrence and Fate of the Pharmaceutical Drug Diclofenac in Surface Waters: Rapid Photodegradation in a Lake. Environ. Sci. Technol. 1998, 32 (22), 3449-3456.

(155) Zhou, N. A.; Lutovsky, A. C.; Andaker, G. L.; Gough, H. L.; Ferguson, J. F. Cultivation and Characterization of Bacterial Isolates Capable of Degrading Pharmaceutical and Personal Care Products for Improved Removal in Activated Sludge Wastewater Treatment. Biodegradation 2013, 24 (6), 813-827.

(156) Luo, Y.; Guo, W.; Ngo, H. H.; Nghiem, L. D.; Hai, F. I.; Zhang, J.; Liang, S.; Wang, X. C. A Review on the Occurrence of Micropollutants in the Aquatic Environment and Their Fate and Removal during Wastewater Treatment. Sci. Total Environ. 2014, 473-474, 619-641.

(157) Fang, Y.; Karnjanapiboonwong, A.; Chase, D. A.; Wang, J.; Morse, A. N.; Anderson, T. A. Occurrence, Fate, and Persistence of Gemfibrozil in Water and Soil. Environ. Toxicol. Chem. 2012, 31 (3), $550-555$.

(158) Grenni, P.; Patrolecco, L.; Ademollo, N.; Tolomei, A.; Barra Caracciolo, A. Degradation of Gemfibrozil and Naproxen in a River Water Ecosystem. Microchem. J. 2013, 107, 158-164.

(159) Kang, S.-I.; Kang, S.-Y.; Kanaly, R. A.; Lee, E.; Lim, Y.; Hur H.-G. Rapid Oxidation of Ring Methyl Groups Is the Primary Mechanism of Biotransformation of Gemfibrozil by the Fungus Cunninghamella Elegans. Arch. Microbiol. 2009, 191 (6), 509-517.

(160) Mrozik, W.; Stefańska, J. Adsorption and Biodegradation of Antidiabetic Pharmaceuticals in Soils. Chemosphere 2014, 95, 281288.

(161) Igos, E.; Benetto, E.; Venditti, S.; Kohler, C.; Cornelissen, A.; Moeller, R.; Biwer, A. Is It Better to Remove Pharmaceuticals in Decentralized or Conventional Wastewater Treatment Plants? A Life 
Cycle Assessment Comparison. Sci. Total Environ. 2012, 438, 533540.

(162) Dionisi, D.; Bornoroni, L.; Mainelli, S.; Majone, M.; Pagnanelli, F.; Papini, M. P. Theoretical and Experimental Analysis of the Role of Sludge Age on the Removal of Adsorbed Micropollutants in Activated Sludge Processes. Ind. Eng. Chem. Res. 2008, 47 (17), 6775-6782.

(163) Byrns, G. The Fate of Xenobiotic Organic Compounds in Wastewater Treatment Plants. Water Res. 2001, 35 (10), 2523-2533.

(164) Dionisi, D.; Bertin, L.; Bornoroni, L.; Capodicasa, S.; Papini, M. P.; Fava, F. Removal of Organic Xenobiotics in Activated Sludges under Aerobic Conditions and Anaerobic Digestion of the Adsorbed Species. J. Chem. Technol. Biotechnol. 2006, 81 (9), 1496-1505.

(165) Hoehler, T. M. Biological Energy Requirements as Quantitative Boundary Conditions for Life in the Subsurface. Geobiology 2004, 2 (4), 205-215.

(166) Isaacs, S. H.; Henze, M.; Søeberg, H.; Kümmel, M. External Carbon Source Addition as a Means to Control an Activated Sludge Nutrient Removal Process. Water Res. 1994, 28 (3), 511-520.

(167) Nyberg, U.; Andersson, B.; Aspegren, H. Long-Term Experiences with External Carbon Sources for Nitrogen Removal. Water Sci. Technol. 1996, 33 (12), 109-116.

(168) Armenante, P. M.; Kafkewitz, D.; Lewandowski, G. A.; Jou, C.-J. Anaerobic-aerobic Treatment of Halogenated Phenolic Compounds. Water Res. 1999, 33 (3), 681-692.

(169) Dickel, O.; Haug, W.; Knackmuss, H.-J. Biodegradation of Nitrobenzene by a Sequential Anaerobic-Aerobic Process. Biodegradation 1993, 4 (3), 187-194.

(170) Rajaguru, P.; Kalaiselvi, K.; Palanivel, M.; Subburam, V. Biodegradation of Azo Dyes in a Sequential Anaerobic-Aerobic System. Appl. Microbiol. Biotechnol. 2000, 54 (2), 268-273.

(171) Gadipelly, C.; Pérez-González, A.; Yadav, G. D.; Ortiz, I.; Ibáñez, R.; Rathod, V. K.; Marathe, K. V. Pharmaceutical Industry Wastewater: Review of the Technologies for Water Treatment and Reuse. Ind. Eng. Chem. Res. 2014, 53 (29), 11571-11592.

(172) Grandclément, C.; Seyssiecq, I.; Piram, A.; Wong-WahChung, P.; Vanot, G.; Tiliacos, N.; Roche, N.; Doumenq, P. From the Conventional Biological Wastewater Treatment to Hybrid Processes, the Evaluation of Organic Micropollutant Removal: A Review. Water Res. 2017, 111, 297-317.

(173) Belgiorno, V. N. V. Wastewater Treatment by Combination of Advanced Oxidation Processes and Conventional Biological Systems. J. Biorem. Biodegrad. 2013, 4, 1-8.

(174) Litter, M.; Candal, R. J.; Meichtry, J. Advanced Oxidation Technologies - Sustainable Solutions for Environmental Treatments, 1st ed.; CRC Press: London, 2017.

(175) Mansour, F.; Al-Hindi, M.; Yahfoufi, R.; Ayoub, G. M.; Ahmad, M. N. The Use of Activated Carbon for the Removal of Pharmaceuticals from Aqueous Solutions: A Review. Rev. Environ. Sci. Bio/Technol. 2018, 17 (1), 109-145.

(176) Wong, S.; Ngadi, N.; Inuwa, I. M.; Hassan, O. Recent Advances in Applications of Activated Carbon from Biowaste for Wastewater Treatment: A Short Review. J. Cleaner Prod. 2018, 175, 361-375.

(177) Zanella, O.; Tessaro, I. C.; Féris, L. A. Desorption- and Decomposition-Based Techniques for the Regeneration of Activated Carbon. Chem. Eng. Technol. 2014, 37 (9), 1447-1459.

(178) Calisto, V.; Silva, C. P.; Esteves, V. I.; Jaria, G.; Otero, M. Waste-Based Alternative Adsorbents for the Remediation of Pharmaceutical Contaminated Waters: Has a Step Forward Already Been Taken? Bioresour. Technol. 2018, 250, 888-901.

(179) Quesada, H. B.; Baptista, A. T. A.; Cusioli, L. F.; Seibert, D.; de Oliveira Bezerra, C.; Bergamasco, R. Surface Water Pollution by Pharmaceuticals and an Alternative of Removal by Low-Cost Adsorbents: A Review. Chemosphere 2019, 222, 766.

(180) Alvares, A. B. C.; Diaper, C.; Parsons, S. A. Partial Oxidation by Ozone to Remove Recalcitrance from Wastewaters - a Review. Environ. Technol. 2001, 22 (4), 409-427.
(181) Andreozzi, R.; Marotta, R.; Pinto, G.; Pollio, A. Carbamazepine in Water: Persistence in the Environment, Ozonation Treatment and Preliminary Assessment on Algal Toxicity. Water Res. 2002, 36 (11), 2869-2877.

(182) Dantas, R. F.; Canterino, M.; Marotta, R.; Sans, C.; Esplugas, S.; Andreozzi, R. Bezafibrate Removal by Means of Ozonation: Primary Intermediates, Kinetics, and Toxicity Assessment. Water Res. 2007, 41 (12), 2525-2532.

(183) Illés, E.; Szabó, E.; Takács, E.; Wojnárovits, L.; Dombi, A.; Gajda-Schrantz, K. Ketoprofen Removal by $\mathrm{O} 3$ and O3/UV Processes: Kinetics, Transformation Products and Ecotoxicity. Sci. Total Environ. 2014, 472, 178-184.

(184) Batista, A. P. S.; Nogueira, R. F. P. Parameters Affecting Sulfonamide Photo-Fenton Degradation - Iron Complexation and Substituent Group. J. Photochem. Photobiol., A 2012, 232, 8-13.

(185) Velásquez, M.; Santander, I. P.; Contreras, D. R.; Yáñez, J.; Zaror, C.; Salazar, R. A.; Pérez-Moya, M.; Mansilla, H. D. Oxidative Degradation of Sulfathiazole by Fenton and Photo-Fenton Reactions. J. Environ. Sci. Health, Part A: Toxic/Hazard. Subst. Environ. Eng. 2014, 49 (6), 661-670.

(186) González, O.; Sans, C.; Esplugas, S.; Malato, S. Application of Solar Advanced Oxidation Processes to the Degradation of the Antibiotic Sulfamethoxazole. Photochem. Photobiol. Sci. 2009, 8 (7), $1032-1039$

(187) Woisetschläger, D.; Humpl, B.; Koncar, M.; Siebenhofer, M. Electrochemical Oxidation of Wastewater - Opportunities and Drawbacks. Water Sci. Technol. 2013, 68 (5), 1173-1179.

(188) Domínguez, J. R.; González, T.; Palo, P.; Sánchez-Martín, J.; Rodrigo, M. A.; Sáez, C. Electrochemical Degradation of a Real Pharmaceutical Effluent. Water, Air, Soil Pollut. 2012, 223 (5), 26852694.

(189) Brillas, E.; Sirés, I.; Arias, C.; Cabot, P. L.; Centellas, F.; Rodríguez, R. M.; Garrido, J. A. Mineralization of Paracetamol in Aqueous Medium by Anodic Oxidation with a Boron-Doped Diamond Electrode. Chemosphere 2005, 58 (4), 399-406.

(190) Brillas, E.; Garcia-Segura, S.; Skoumal, M.; Arias, C. Electrochemical Incineration of Diclofenac in Neutral Aqueous Medium by Anodic Oxidation Using Pt and Boron-Doped Diamond Anodes. Chemosphere 2010, 79 (6), 605-612. 